\title{
Viral hemorrhagic septicemia virus, Ichthyophonus hoferi, and other causes of morbidity in Pacific herring Clupea pallasi spawning in Prince William Sound, Alaska, USA
}

\author{
Gary D. Marty ${ }^{1, *}$, Ellen F. Freiberg ${ }^{1}$, Theodore R. Meyers ${ }^{2}$, John Wilcock ${ }^{3}$, \\ Thomas B. Farver ${ }^{4}$, David E. Hinton ${ }^{1}$ \\ 'Department of Anatomy, Physiology, and Cell Biology, School of Veterinary Medicine, University of California, \\ One Shields Avenue, Davis, California 95616, USA \\ ${ }^{2}$ Alaska Department of Fish and Game, Juneau Fish Pathology Laboratory, PO Box 25526, Juneau, Alaska 99802, USA \\ ${ }^{3}$ Alaska Department of Fish and Game, PO Box 669, Cordova, Alaska 99574, USA \\ ${ }^{4}$ Department of Population Health and Reproduction, School of Veterinary Medicine, University of California, Davis, \\ California 95616, USA
}

\begin{abstract}
Pacific herring Clupea pallasi populations in Prince William Sound, Alaska, USA, declined from an estimated $9.8 \times 10^{7} \mathrm{~kg}$ in 1992 to $1.5 \times 10^{7} \mathrm{~kg}$ in 1994 . To determine the role of disease in population decline, 233 Pacific herring from Prince William Sound were subjected to complete necropsy during April 1994. The North American strain of viral hemorrhagic septicemia virus (VHSV) was isolated from 11 of 233 fish $(4.7 \%)$. VHSV was significantly related to myocardial mineralization, hepatocellular necrosis, submucosal gastritis, and meningoencephalitis. Ichthyophonus hoferi infected 62 of $212(29 \%)$ fish. I. hoferi infections were associated with severe, disseminated, granulomatous inflammation and with increased levels of plasma creatine phosphokinase (CPK) and aspartate aminotransferase (AST). L. hoferi prevalence in 1994 was more than double that of most previous years (1989 to 1993). Plasma chemistry values significantly greater $(p<0.01)$ in males than females included albumin, total protein, cholesterol, chloride, glucose, and potassium; only alkaline phosphatase was significantly greater in females. Hypoalbuminemia was relatively common in postspawning females; other risk factors included VHSV and moderate or severe focal skin reddening. Pacific herring had more than. 10 species of parasites, but they were not associated with significant lesions. Two of the parasites have not previously been described: a renal intraductal myxosporean ( $11 \%$ prevalence) and an intestinal coccidian (91\% prevalence). Transmission electron microscopy of a solitary mesenteric lesion revealed viral particles consistent with lymphocystis virus. No fish had viral erythrocytic necrosis (VEN). Prevalence of external gross lesions and major parasites was not related to fish age, and fish that were yearlings at the time of the 1989 'Exxon Valdez' oil spill (1988 year class) had no evidence of increased disease prevalence.
\end{abstract}

KEY WORDS: Clupea pallasi - 'Exxon Valdez' - Histopathology · Hypoalbuminemia · Ichthyophonus hofen · Pacific herring · Plasma chemistries - Viral hemorrhagic septicemia virus (VHSV)

\section{INTRODUCTION}

Pacific herring Clupea pallasi are among the most abundant fish species in coastal regions of the North Pacific, where they are important for commercial and

•E-mail: gdmarty@ucdavis.edu subsistence fishing and as prey for many marine fish, birds, and mammals. In Prince William Sound (PWS), Alaska, Pacific herring normally support 5 commercial fisheries, with an average annual ex-vessel value of $\$ 8.3$ million. Roe fisheries, the most valuable, are harvested in April just before spawning. Pacific herring in PWS first spawn when 3 or 4 yr old; they rarely live 
more than 12 yr, and abundant year classes recruit into the fishery about once every 4 yr. When the 'Exxon Valdez' oil spill occurred in March 1989, the biomass of spawning Pacific herring in PWS was the highest in $20 \mathrm{yr}$ of reliable estimates (about $102 \times 10^{6} \mathrm{~kg}$; Fig. 1). The population declined about $10 \%$ each of the first $2 \mathrm{yr}$ after the spill, but then increased to $98 \times 10^{6} \mathrm{~kg}$ in 1992 (Fig. 1).

Because toxicants such as crude oil cause relatively more severe damage in younger fish, particularly larvae (McKim 1985), long-term effects of the oil spill were thought most likely to occur in the 1988 and 1989 year classes which entered the spawning population in 1992 and 1993. Indeed, preliminary study of 4-yr-old PWS Pacific herring in 1992 revealed less reproductive success in fish spawning in previously oiled sites than in unoiled sites, and fish with poor reproductive success had more severe microscopic lesions (Kocan et al. 1996). Pacific herring biomass was stable in 1992, and recruitment from the 1988 year class was expected to be excellent; therefore, fisheries biologists predicted a record spawning biomass of $110 \times 10^{6} \mathrm{~kg}$ before the 1993 spawning season (Fig. 1). However, when the 1993 spawning season commenced, barely $20 \%$ of the expected biomass appeared. Fish were lethargic, and many had external hemorrhages. Unlike reported disease outbreaks in Atlantic herring Clupea harengus (Fish 1934, Sindermann 1958, Rahimian \& Thulin 1996 , Mellergaard \& Spanggaard 1997) and Pacific herring (Tester 1942), there were no reports of dead fish to explain differences in predicted and actual biomass in PWS. The North American strain of viral hemorrhagic septicemia virus (VHSV) was isolated from pooled samples of Pacific herring, but no other significant

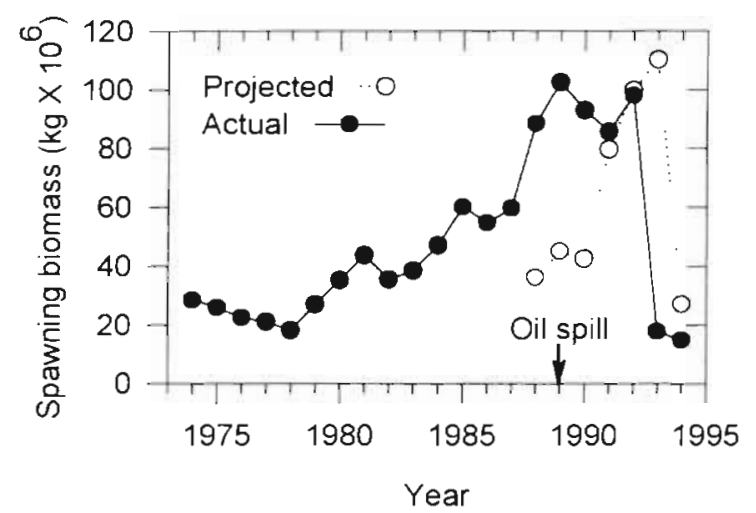

Fig. 1. Clupea pallasi. Biomass estimates of mature Pacific herring in Prince William Sound, Alaska. Unexploited biomass projected in the year before spawning (Projected) and estimated during spawning (Actual). Estimates were made by Fritz Funk, Alaska Department of Fish and Game, Juneau, Alaska; unpubl. data. Note that the model for projecting population biomass was not used before 1988 pathogens were isolated (Meyers et al. 1994). Because VHSV isolation had not previously been reported from Pacific herring, the role of VHSV in population decline could not be determined. By 1994, spawning biomass declined to the lowest level in 20 yr $\left(15 \times 10^{6} \mathrm{~kg}\right)$. Because of the reduced biomass and the presence of external lesions, commercial fisheries were severely curtailed in 1993 and all Pacific herring fisheries were closed in PWS in 1994. Interpretation of the 1993 VHSV isolates in PWS was confounded by the subsequent isolation of VHSV in several Pacific herring populations throughout the northeastern Pacific (Meyers \& Winton 1995). Was VHSV the primary cause of mortality? Or, was VHSV expressed only in otherwise sick fish?

A comprehensive study was initiated to determine the causes of morbidity in PWS Pacific herring. This paper describes the first results from this multiyear study. Our primary hypothesis was that VHSV was the most important cause of mortality, but the study was designed to identify other pathogens. We had 4 specific objectives: (1) assess the general health of Pacific herring in $\mathrm{PWS}_{i}(2)$ assess the primary or secondary invader role of VHSV in producing disease in PWS Pacific herring; (3) assess the influence of gender and spawning on Pacific herring health; and (4) determine whether fish of a particular year class were more likely to be diseased than other year classes. Petroleum hydrocarbons decreased steadily after the oil spill, and were detected in mussel tissues only in the most contaminated bays in 1991 (Short \& Harris 1996). Continued exposure of Pacific herring to 'Exxon Valdez' oil was considered unlikely in our 1994 samples, and testing for hydrocarbon contamination was not done. Because of the potential for litigation, another research team conducted a separate study of Pacific herring health in Prince William Sound in 1994 (Elston et al. 1997).

This paper describes the pathogens and parasites of Pacific herring in PWS, emphasizing their potential role in population decline. Significant gender differences in plasma chemistries and lesion prevalence are identified. Finally, we discuss research needs to better understand population health and prevention of epizootics.

\section{MATERIALS AND METHODS}

Necropsy. Pacific herring were captured in Rocky Bay of Montague Island, PWS, Alaska, from April 21 through 26, 1994. To obtain a sample representative of the spawning population in PWS, fish were collected by gill net, beach seine, or purse seine in 17 different sets ( 8 to 18 fish per set). After capture, fish were held 
in plastic containers filled with about 100 l of seawater for no more than $4 \mathrm{~h}$ before processing. In groups of 2 , herring were anesthetized in tricaine methane sulfonate (Finquel ${ }^{\circledR}$ ), weighed and measured (standard length), and a scale was removed for age determination. Each fish was assigned a unique identifying number. Several diagnostic procedures were done as part of complete necropsy and subsequent analysis on each of 233 fish:

(1) External lesions-scored as none (0), mild (1), moderate (2), or severe (3). Also, each fish was assigned a summary 'external lesion score' equal to the most severe score for fin base reddening, caudal fin reddening, or focal skin reddening.

(2) Blood - about $1.5 \mathrm{ml}$ of blood was drawn from the caudal vein into $3 \mathrm{ml}$ syringes containing $0.1 \mathrm{ml}$ of sodium heparin (10000 IU ml-1). A capillary tube was filled and centrifuged $(5500 \times g$ for $5 \mathrm{~min})$ for determination of packed cell volume (PCV). A blood smear was made and air-dried. Remaining blood was centrifuged (13600 $\times g$ for $5 \mathrm{~min}$ ) and resultant plasma was frozen for storage until analysis.

Osmolality was analyzed on a Micro Osmometer Model 3MO-plus (Advanced Instruments, Norwood, MA, USA) using $20 \mu \mathrm{l}$ of plasma. All other analyses were done using about $200 \mu$ l of sample in a Monarchplus analyzer (Instrumentation Laboratories, Lexington, MA, USA) calibrated and run at a stabilized $25^{\circ} \mathrm{C}$ Plasma was analyzed for total protein (biuret method), albumin (bromocresol green method), and $\mathrm{CO}_{2}$ (enzymatic method). Instrumentation Laboratories substrates were used to analyze calcium, cholesterol, glucose, phosphorus, total bilirubin, alkaline phosphatase (ALP), alanine aminotransferase (ALT), aspartate aminotransferase (AST), and creatine phosphokinase $(\mathrm{CPK})$. Sigma ${ }^{\oplus}$ (St. Louis, MO, USA) substrates were used to analyze gamma glutamyltransferase (GGT). Ion-selective electrodes were used to analyze sodium, potassium, and chloride. Blood smears were stained with Diff-Quik (Dade Diagnostics, Inc., Aquada, Puerto Rico) and 30 fields $(1000 \times)$ were examined for cytoplasmic inclusions of viral erythrocytic necrosis (VEN).

(3) Virus isolation-head kidney and spleen from each fish were pooled in a plastic bag and shipped on ice to the Alaska Department of Fish and Game Fish Pathology Laboratory in Juneau, Alaska. Skin lesions, if present, were sampled and bagged separately for individual virus assay. Propagation of EPC cell lines, media formulation, and tissue preparation for cell line inoculation were as described by Meyers et al. (1994).

(4) Tissue preservation - samples of gill, liver, gonad, spleen, trunk kidney, gastrointestinal tract, heart, skin, skeletal muscle, and brain were fixed in $10 \%$ neutral buffered formalin.
(5) Bacterial isolation-for fish with moderate or severe external lesions; kidney tissues were aseptically inoculated onto trypticase soy agar (TSA) and plates were incubated at $25^{\circ} \mathrm{C}$ for at least $5 \mathrm{~d}$.

(6) Kidney parasite identification - a touch preparation of kidney (junction of head and trunk kidney) was air-dried, stained with Diff-Quik, and examined for pansporoblasts of the myxosporean Ortholinea orientalis; extent of infection was scored as for external lesions.

(7) Organ weights - liver and gonad were weighed.

(8) Herring worms (Anisakidae)-larvae in the peritoneal cavity were counted.

Histopathologic analysis. Tissues from 233 Pacific herring were sent to the University of California, Davis, and randomly assigned an individual histopathology number for blind study. Tissues from 21 herring had been inadvertently put in water rather than fixative. Therefore, data on histopathology reflect the 212 herring that were adequately fixed. After routine paraffin processing, tissue blocks were sectioned at $5 \mu \mathrm{m}$ and stained with hematoxylin and eosin. Lesions were scored using a 4 -point scale as none (0), mild (1), moderate (2), or severe (3). For quality control, autolysis and artifact in each organ were scored on the same 4-point scale. Ranking of lesions was often based on the number of structures (e.g. Ichthyophonus resting spores) per $100 \times$ field; the $100 \times$ field was examined through a $10 \times$ objective lens and a $10 \times$ ocular lens on an Olympus binocular light microscope. Differentiation of severity scores for each lesion was based on written criteria and 'type specimen' examples. Not all scores were used for each lesion, because many lesions had no examples that were 'severe'. After all organs were examined and lesions scored, data were rearranged by necropsy number and subjected to statistical analysis.

Transmission electron microscopy. After determining that 2 fish had gross and microscopic lesions consistent with lymphocystis virus, more detailed analysis was needed to confirm the presence of viral particles in the lesions. A stained histological section of one suspect cell was removed from the glass slide and processed for transmission electron microscopy as previously described (Meyers et al. 1990).

Statistical analysis. The primary hypothesis was that fish with lesions were different from fish without lesions. The association of categorical variables (e.g. none, mild, moderate, and severe) with continuous variables (e.g. CPK values) was determined using 1-way analysis of variance (1-way ANOVA). For example, the CPK values for fish with a liver Ichthyophonus score of zero were compared to CPK values in fish with mild, moderate, and severe hepatic Ichthyophonus. When necessary, categories were combined to ensure that each group had at 
least 6 fish. Category-specific means and standard errors were calculated for each continuous variable and compared using Tukey's Studentized range method. Levene's test was used to evaluate the homogeneity of variance assumption for the ANOVA.

The association between 2 selected categorical variables (e.g. Ichthyophonus scores versus scores for hepatic focal necrosis) was evaluated using chi-square methods for categorical data analysis; comparisons were considered valid only if individual expected cell frequencies were $>1$. Odds ratios were calculated for standard $(2 \times 2) 2$-way contingency tables only. To measure the strength of the linear relationship between 2 continuous variables, the correlation coefficient $r$ was calculated.

In the initidl univariate analysis, some plasma chemistries were significantly associated with several lesions or other variables. In selected cases, multiple regression analysis was used to model a multifactor ANOVA, examining the relationships between the dependent variable (e.g. plasma albumin) and associated variables (e.g. focal skin reddening, splenic congestion, and VHSV). Lesion scores were forced into a multiple regression equation using stepwise regression to determine their joint impact in the prediction of the dependent variable (e.g. albumin level), while controlling for gender, gonad weight, hold time, and length. Criteria used for inclusion of variables in the evaluation included significance in the univariate analysis and postulated association of the equation variable with the dependent variable. Length was used rather than age or weight for 2 reasons: (1) length was more normally distributed than was age; and (2) length was more consistent in spawning fish than was weight.

To determine if certain age classes of fish were more likely to be infected by certain parasites, the association of fish age with common parasites was evaluated using the chi-square test for homogeneity. Fish were grouped into 3 categories for analysis: $<5$ yr old, 5 or 6 yr old, or $>6$ yr old. Regardless of severity of infestation, fish with a given parasite were classified as positive, and fish without the parasite were classified as negative.

For all analyses, comparisons were considered significant when $\mathrm{p}<0.05$ and highly significant when $p<0.01$. For this report, use of the term 'prevalence' refers to the sample prevalence.

\section{RESULTS}

\section{External gross lesions}

The summary external lesion score was moderate or severe in 47 of 233 fish ( $20 \%$ ), and several of these fish concurrently had more than one lesion graded as moderate or severe. Seven of 233 (3.0\%) had ulcers (scored as severe focal skin reddening; Table 1, Fig. 2A, B). Some ulcers penetrated to underlying bone and one ulcer perforated into the peritoneal cavity, resulting in adhesions of viscera to the body wall. External lesions were significantly associated with several microscopic lesions. For example, increased scores for focal skin reddening were associated with increased scores for gill arch inflammation or hematopoiesis, submucosal gastritis, intestinal mesenteric steatitis, and renal hematopoietic cells. By comparison, scores for hepatic parenchymal leukocytes decreased as scores for focal skin reddening increased. The relationship among other gross lesions and histologic lesions were not consistent.

Because of the lack of published information on normal Pacific herring gross and microscopic anatomy, some findings were scored without knowledge of whether they were in fact lesions. Iris reddening is a good example. The inferior margin of the iris has a blood vessel about $3 \mathrm{~mm}$ long and $0.5 \mathrm{~mm}$ in diameter. Iris reddening occurred when the vessel contained enough blood to be detected by gross observation (Fig. 2C). Scores for iris reddening were assigned as follows: no reddening (0); reddening was limited to the primary vessel (1); reddening extended beyond the margins of the primary vessel, probably due to congestion of connecting venules (2); and reddening involved the entire iris (3). No fish had severe iris reddening, and mild iris reddening probably was normal. Several lesions were more prevalent in fish with no iris reddening than in fish with mild or moderate iris reddening (Table 2). For example, branchial ciliated protozoa and meningoencephalitis were more likely in fish with no iris reddening. Also, mean albumin and total protein were significantly lower in fish with no iris reddening than in fish with mild iris reddening (albumin, 0.46 vs. $0.54 \mathrm{~g} \mathrm{dl}^{-1}$; total protein, 2.0 vs $2.3 \mathrm{~g} \mathrm{dl}^{-1}$ ).

Fig. 2. Clupea pallasi. Gross and histologic lesions in Pacific herring sampled from Prince William Sound, Alaska, during spawning, 1994. (A) The ulcer with neovascularization on the right lateral side of this $198 \mathrm{~mm}$ long female was positive for viral hemorrhagic septicemia virus (VHSV). (B) A similar ulcer on the dorsal caudal peduncle of a $245 \mathrm{~mm}$ long female was negative for VHSV. (C) Mild reddening of the ventral region of the iris (arrow) was considered normal; this fish was released and not cultured for VHSV. (D) Normal gastric submucosa with large numbers of eosinophilic granular leukocytes. (E) Gastric submucosa with increased numbers of lymphocytes and macrophages (i.e. submucosal gastritis). (D) and (E): hematoxylin and eosin stain g: gastric glands; same magnification, bar length $=100 \mu \mathrm{m}$ 


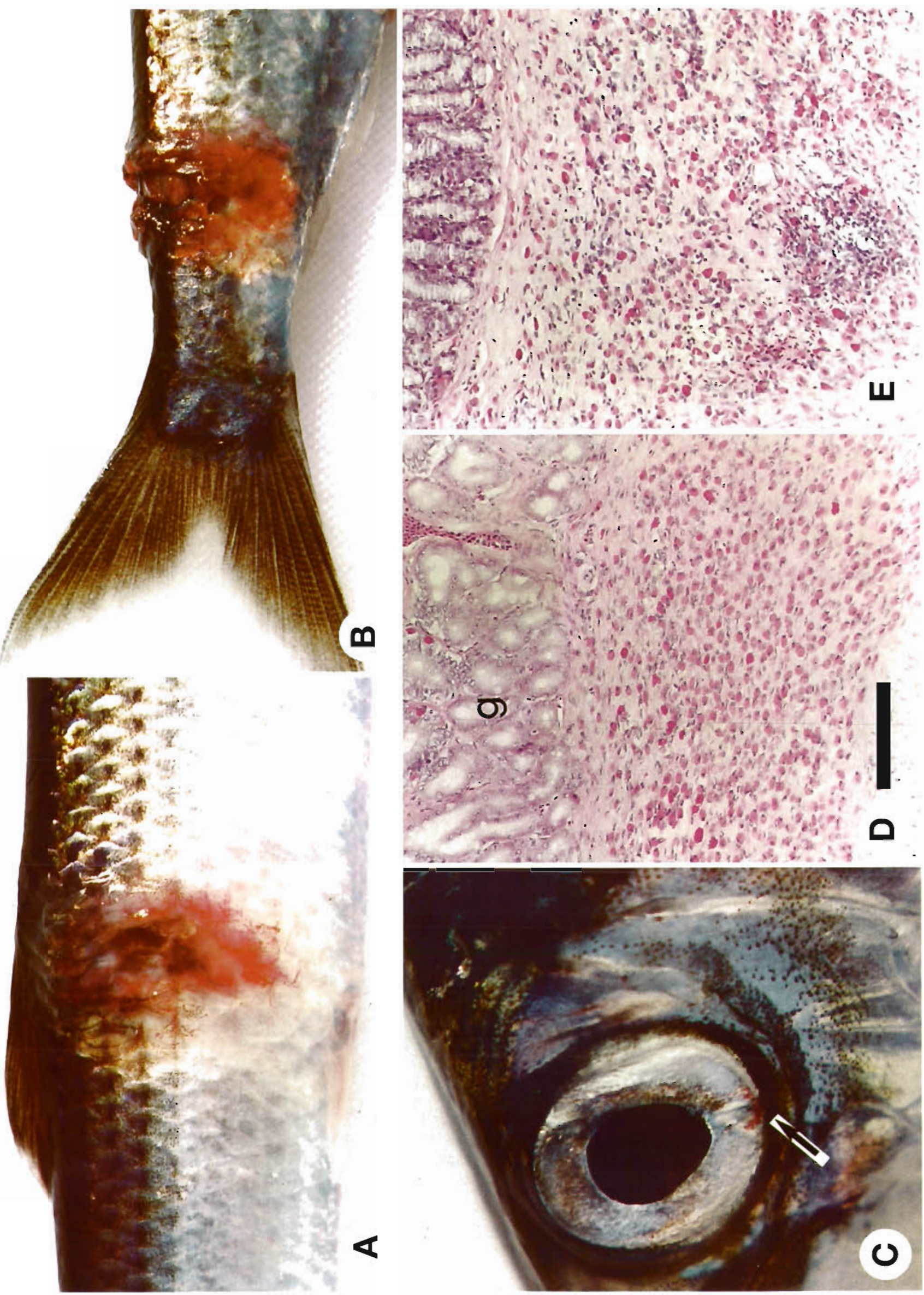


Table 1. Clupea pallası. Lesion severity (number of fish classified in each lesion scorel and prevalence (\% of sample having lesion score >0) in mature Pacific herring sampled from Prince William Sound, Alaska, during spawning, 1994. Lesions were scored as none (0), mild (1), moderate (2), or severe (3). Age, hold time, and blood values were compared for groups of fish based on lesion scores using 1 -way analysis of variance and Tukey's multiple comparison procedure Signıficant trends were based on rank order of mean respunses for tish groups classitied by lesıon scores. Compared to fish with the lowest lesion score, mean response for the fish group with the highest lesion score was significantly higher ( $\uparrow$ ), lower ( $\downarrow$ ), or there was no significant trend (NT) in the rank order. For comparisons in which Levene's test for equality of variance was significant ("), only comparisons with $p \leq 0.010$ are shown

\begin{tabular}{|c|c|c|c|c|c|c|}
\hline Organ; lesion or tissue type & \multicolumn{4}{|c|}{ Lesion score } & $\begin{array}{l}\text { Sample } \\
\text { prevalence }\end{array}$ & Significant trends ( $p$-value) \\
\hline \multicolumn{7}{|l|}{ External gross lesions } \\
\hline Caudal fin fraying $(n=233)$ & 39 & 177 & 15 & 2 & 83 & \multirow{5}{*}{$\begin{array}{l}\uparrow \text { calcium }\left(0.005^{\circ}\right) \text {, osmolality }(0.008) \\
\downarrow \text { ALP }(0.022) \\
\uparrow \text { hold time }(<0.001) \text {, osmolality }(0.005) \\
\downarrow \text { chloride }(0.050) \\
\uparrow \text { albumin }(0.003) \text {, ALP }(<0.001) \text {, Calcium }(<0.001) \text {, chloride } \\
(<0.001) \text {, cholesterol }(0.017) \text {, osmolality }(<0.001) \text {, phosphorus } \\
\left(<0.001^{\circ}\right) \text {, potassium }\left(<0.001^{\circ}\right) \text {, total protein }(<0.001) \\
\downarrow C O 2(0.006) \\
\uparrow \text { chloride }(0.002) \\
\downarrow \text { albumin }(<0.001) \text {, ALP }(<0.001) \text {, calcium }(0.034) \text {, cholesterol } \\
\left(<0.001 \cdot, \text { total protein }\left(<0.001^{\prime}\right)\right. \\
\text { NT: PCV }(0.043)\end{array}$} \\
\hline Caudal fin reddening $(n=233)$ & 127 & 95 & 9 & 2 & 45 & \\
\hline Fin base reddening $(n=233)$ & 112 & 89 & 29 & 3 & 51 & \\
\hline Iris reddening $(n=205)$ & 100 & 100 & 5 & 0 & 51 & \\
\hline $\begin{array}{l}\text { Skin reddening, focal } \\
\text { (includes ulcers; } \mathrm{n}=227 \text { ) }\end{array}$ & 148 & 60 & 12 & 7 & 35 & \\
\hline \multicolumn{7}{|l|}{ Brain microscopic lesions $(n=212)$} \\
\hline Ichthyophonus & 195 & 16 & 1 & 0 & 8.0 & $\begin{array}{l}\uparrow \operatorname{AST}(0.002 \cdot), \log _{e} \text { AST }(<0.001), C P K(<0.001), \log _{e} C P K \\
(<0.001), \text { potassium }(0.021), \text { total protein }(0.023) \\
\uparrow \operatorname{PCV}(0.049)\end{array}$ \\
\hline $\begin{array}{l}\text { Meningeal eosinophilic } \\
\text { granular leukocytes }\end{array}$ & 28 & 142 & 39 & 3 & 87 & NT: GGT $(0.007)$ \\
\hline Meningoencephalitis & 205 & 6 & 1 & 0 & 3.3 & $\uparrow$ age $\left(0.003^{\circ}\right)$ \\
\hline \multicolumn{7}{|l|}{ Gall bladder microscopic lesions $(\mathrm{n}=171)$} \\
\hline \multicolumn{7}{|c|}{ Ichthyophonus (score combined with liver Ichthyophonus) } \\
\hline \multicolumn{7}{|l|}{ Gill microscopic lesions $(n=212)$} \\
\hline Ciliated protozoa (e.g. Trichodina spp.) & 187 & 25 & 0 & 0 & 12 & $\downarrow$ chlonde $(0.035)$ \\
\hline Epitheliocystis & 190 & 20 & 2 & 0 & 10 & none \\
\hline Foreign body granuloma & 193 & 19 & 0 & 0 & 9.0 & none \\
\hline Gill arch inflammation or hematopoiesis & s 1 & 161 & 39 & 0 & 100 & $\begin{array}{l}\downarrow \text { albumin }(0.003) \text {, ALP }(0.004) \text {, calcium }(0.011) \text {, cholesterol } \\
(0.009) \text {, osmolality }(0.048)\end{array}$ \\
\hline IChthyophonus & 185 & 18 & 5 & 4 & 13 & $\begin{aligned} \text { NT: } & \text { AST }\left(0.003^{\circ}\right), \log _{e} \text { AST }(0.003), C P K\left(<0.0011^{\prime}\right), \log _{e} \text { CPK } \\
& (<0.001), \text { total protein }(0.001)\end{aligned}$ \\
\hline Lamellar hyperplasia & 204 & 7 & 1 & 0 & 3.8 & $\uparrow$ glucose $(0.048)$ \\
\hline $\begin{array}{l}\text { Monogenetic trematodes } \\
\text { (e.g. Gyrodactylus spp.) }\end{array}$ & 185 & 27 & 0 & 0 & 13 & none \\
\hline \multicolumn{7}{|l|}{ Gonad - female $(n=110)$ microscopic lesions } \\
\hline Eosinophilic granular leukocytes & 38 & 53 & 19 & 0 & 65 & NT: phosphorus $(0.006)$ \\
\hline Granulomatous inflammation & 108 & 1 & 1 & 0 & 1.8 & none \\
\hline $\begin{array}{l}\text { Hyalinization of vessel walls } \\
\text { Ichthyophonus }\end{array}$ & $\begin{array}{r}43 \\
108\end{array}$ & $\begin{array}{r}57 \\
2\end{array}$ & $\begin{array}{r}10 \\
0\end{array}$ & $\begin{array}{l}0 \\
0\end{array}$ & 61 & $\begin{array}{l}\text { none } \\
\text { none }\end{array}$ \\
\hline Macrophage aggregates (pigmented) & 40 & 68 & 2 & 0 & $64^{1.0}$ & $\uparrow$ age $(<0.001)$ \\
\hline \multicolumn{7}{|l|}{ Gonad - male $(n=102)$ microscopic lesions } \\
\hline Eimena sardinae & 44 & 52 & 6 & 0 & 57 & $\uparrow \operatorname{ALT}\left(0.006^{*}\right)$ \\
\hline Eosinophilic granular leukocytes & 45 & 34 & 22 & 1 & 56 & $\downarrow$ calcium $(0.051)$ \\
\hline Granulomatous inflammation & 93 & 8 & 0 & 1 & 8.8 & none \\
\hline $\begin{array}{l}\text { Hyalinization of vessel walls } \\
\text { Ichthyophonus }\end{array}$ & $\begin{array}{l}102 \\
101\end{array}$ & $\begin{array}{l}0 \\
0\end{array}$ & $\begin{array}{l}0 \\
0\end{array}$ & $\begin{array}{l}0 \\
1\end{array}$ & & $\begin{array}{l}N^{d} \\
N D\end{array}$ \\
\hline Macrophage aggregates (pigmented) & 99 & 3 & 0 & 0 & 2.9 & - \\
\hline Spermatocyte numbers $(3=$ abundant $)$ & 9 & 23 & 30 & 40 & $N A^{e}$ & $\begin{array}{l}\uparrow \text { glucose }(<0.001) \text {, osmolality }<0.001) \text {, total protein }\left(<0.001^{*}\right) \\
\text { NT: albumin }(0.001) \text {, ALP }(0.001) \text {, chloride }(0.021)\end{array}$ \\
\hline \multicolumn{7}{|l|}{ Heart microscopic lesions $(n=210)$} \\
\hline Epicarditis & 105 & 105 & 0 & 0 & 50 & $\downarrow$ age 10.017$)$ \\
\hline Ichthyophonus & 172 & 14 & 12 & 12 & 18 & $\begin{array}{l}\uparrow \text { CPK }\left(<0.001^{\prime}\right), \log _{e} \text { CPK }(<0.001) \\
\text { NT: AST }\left(<0.001^{\circ}\right), \log _{e} \text { AST }(<0.001 \cdot) \text {, total protein }(0.001)\end{array}$ \\
\hline Leukocytes, focal, parenchymal & 107 & 103 & 0 & 0 & 49 & $\downarrow$ glucose $(0.020)$, total protein $(0.009)$ \\
\hline Mineralization, myocardial & 208 & 2 & 0 & 0 & 0.9 & $\uparrow \operatorname{ALT}\left(0.003^{\circ}\right)$ \\
\hline Thrombosis & 193 & 16 & 0 & 0 & 8.1 & $\begin{array}{l}\uparrow \operatorname{AST}\left(<0.001^{\circ}\right), \log _{e} \text { AST }\left(0.008^{\circ}\right), \text { CPK }(<0.001 *) \\
\log _{e} \text { CPK }(0.004) \\
\downarrow \text { PCV }(0.026)\end{array}$ \\
\hline \multicolumn{7}{|c|}{ Intestine and intestinal cecae, microscopic lesions ( $n=211$ ) } \\
\hline Anisakidae & 51 & 137 & 23 & 0 & 76 & none \\
\hline Arteriolar hyperplasia, focal, intimal & 133 & 76 & 2 & 0 & 37 & none \\
\hline Cestodes & 206 & 1 & 4 & 0 & 2.4 & ND \\
\hline Coccidian, intraepithelial (Goussia sp.?) & 19 & 190 & 2 & 0 & 91 & $\downarrow$ osmolality $(0.028)$ \\
\hline $\begin{array}{l}\text { Eosinophilic granular leukocytes, } \\
\text { submucosal }\end{array}$ & 0 & 202 & 9 & 0 & 100 & $\uparrow \operatorname{ALP}(0.033)$ \\
\hline Foreign body granuloma & 133 & 78 & 0 & 0 & 37 & none \\
\hline Ichthyophonus & 193 & 17 & 1 & 0 & 8.5 & $\left\{\log _{e}\right.$ AST $(0.031)$, CPK $(<0.001)^{\circ}, \log _{e}$ CPK $(0.008)$ \\
\hline Steatitis & 0 & 184 & 27 & 0 & 100 & TAST $\left(<0.001^{\circ}\right), \log _{e}$ AST $\left(0.002^{\circ}\right)$ \\
\hline $\begin{array}{l}\text { Trematodes } \\
\text { (e.g. Lecithaster gibbosus), cecal }\end{array}$ & 205 & 6 & 0 & 0 & 2.9 & none \\
\hline
\end{tabular}


Table 1 (continued)

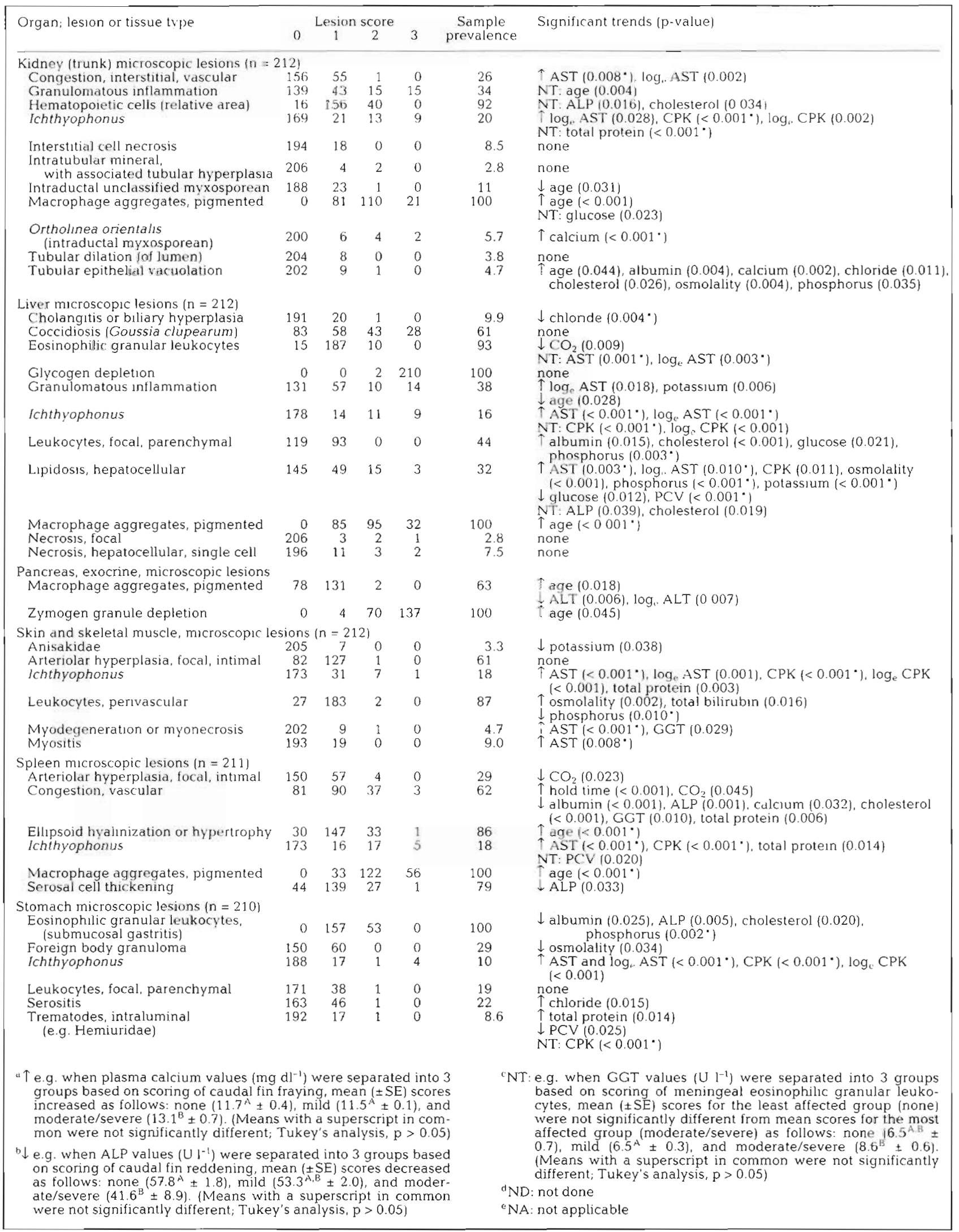


Table 2. Clupea pallasi. Lesion frequency (\%) within variables of gender, iris reddening, and viral hemorrhagic septicemia virus (VHSV) in Pacific herring sampled from Prince Willam Sound, Alaska, dunng spawning, 1994. Lesions were scored as none (0), mild (1), moderate (2), or severe (3). Chi-square test for homogeneity. Lesions not listed were not significant. For some lesions, sum of individual frequencies within a category is different from $100 \%$ duc to rounding differences

\begin{tabular}{|c|c|c|c|c|c|c|}
\hline \multirow{2}{*}{$\begin{array}{l}\text { Variable and lesion } \\
\text { Gender }\end{array}$} & \multirow[t]{2}{*}{ Lesion score } & \multicolumn{2}{|c|}{ Frequency } & \multirow[t]{2}{*}{$\chi^{2} p$-value ${ }^{b}$} & \multirow[t]{2}{*}{ Odds ratio } & \multirow{2}{*}{$\begin{array}{l}95 \% \text { Confidence interval } \\
\text { for odds ratio }\end{array}$} \\
\hline & & $\begin{array}{l}\text { Female } \\
(n \approx 110)\end{array}$ & $\begin{array}{c}\text { Male } \\
(\mathbf{n} \approx 102)\end{array}$ & & & \\
\hline $\begin{array}{c}\text { Gall bladder myxosporeans } \\
\text { (Ceratomyxa auerbachi) }\end{array}$ & $\begin{array}{c}0 \\
1+2\end{array}$ & $\begin{array}{l}73 \\
27\end{array}$ & $\begin{array}{l}90 \\
10\end{array}$ & 0.003 & 3.5 & $1.5,8.4$ \\
\hline $\begin{array}{l}\text { Gonadal granulomas (or focal } \\
\text { granulomatous inflammation) }\end{array}$ & $\stackrel{0}{1+2+3}$ & $\begin{array}{r}98 \\
2\end{array}$ & $\begin{array}{r}91 \\
9\end{array}$ & 0.022 & 0.2 & $0.0,0.9$ \\
\hline Gonadal hyalinized vessel walls & $\begin{array}{l}0 \\
1 \\
2\end{array}$ & $\begin{array}{r}39 \\
52 \\
9\end{array}$ & $\begin{array}{r}100 \\
0 \\
0\end{array}$ & $<0.001$ & $N C^{c}$ & $\mathrm{NC}$ \\
\hline $\begin{array}{l}\text { Gonadal pigmented } \\
\text { macrophage aggregates }\end{array}$ & $\begin{array}{c}0 \\
1+2\end{array}$ & $\begin{array}{l}36 \\
64\end{array}$ & $\begin{array}{r}97 \\
3\end{array}$ & $<0.001$ & 58 & 17,190 \\
\hline Intestinal mesenteric steatitis & $\begin{array}{l}1 \\
2\end{array}$ & $\begin{array}{r}92 \\
8\end{array}$ & $\begin{array}{l}82 \\
18\end{array}$ & 0.036 & 0.4 & $0.2,1.0$ \\
\hline $\begin{array}{l}\text { Renal proximal tubular } \\
\text { epithelial vacuolation }\end{array}$ & $\begin{array}{c}0 \\
1+2\end{array}$ & $\begin{array}{r}99 \\
1\end{array}$ & $\begin{array}{r}91 \\
9\end{array}$ & 0.007 & 0.1 & $0.0,0.8$ \\
\hline Renal tubular dilation (of lumen) & $\begin{array}{l}0 \\
1\end{array}$ & $\begin{array}{c}99 \\
1\end{array}$ & $\begin{array}{r}93 \\
7\end{array}$ & 0.023 & 0.1 & $0.0,1.0$ \\
\hline Splenic Ichthyophonus & $\begin{array}{c}0 \\
1 \\
2+3\end{array}$ & $\begin{array}{r}83 \\
4 \\
14\end{array}$ & $\begin{array}{r}82 \\
12 \\
7\end{array}$ & 0.031 & $\mathrm{NC}$ & $\mathrm{NC}$ \\
\hline Iris reddening & & $\begin{array}{l}\text { Mild/moderate } \\
\qquad(\mathrm{n}=93)\end{array}$ & $\begin{array}{c}\text { None } \\
(n=94)\end{array}$ & & & \\
\hline Branchial ciliated protozoa & $\begin{array}{l}0 \\
1\end{array}$ & $\begin{array}{r}95 \\
5\end{array}$ & $\begin{array}{l}82 \\
18\end{array}$ & 0.007 & 0.3 & $0.1,0.7$ \\
\hline Caudal fin fraying & $\begin{array}{c}0 \\
1 \\
2+3\end{array}$ & $\begin{array}{r}10 \\
85 \\
6\end{array}$ & $\begin{array}{r}22 \\
73 \\
5\end{array}$ & 0.049 & $\mathrm{NC}$ & $\mathrm{NC}$ \\
\hline Fin base reddening & $\begin{array}{c}0 \\
1 \\
2+3\end{array}$ & $\begin{array}{r}59 \\
32 \\
9\end{array}$ & $\begin{array}{l}36 \\
44 \\
20\end{array}$ & 0.002 & NC & $\mathrm{NC}$ \\
\hline Meningoencephalitıs & $\begin{array}{c}0 \\
1+2\end{array}$ & $\begin{array}{r}100 \\
0\end{array}$ & $\begin{array}{r}96 \\
4\end{array}$ & 0.044 & 0.0 & $\mathrm{NC}$ \\
\hline $\begin{array}{c}\text { Pancreatic zymogen } \\
\text { granule depletion }\end{array}$ & $\begin{array}{c}1+2 \\
3\end{array}$ & $\begin{array}{l}27 \\
73\end{array}$ & $\begin{array}{l}44 \\
56\end{array}$ & 0.019 & 2.1 & $1.1,3.8$ \\
\hline Renal congestion & $\begin{array}{c}0 \\
1+2\end{array}$ & $\begin{array}{l}67 \\
33\end{array}$ & $\begin{array}{l}80 \\
20\end{array}$ & 0.043 & 2.0 & $1.0,3.8$ \\
\hline Splenic congestion & $\begin{array}{c}0 \\
1 \\
1+2\end{array}$ & $\begin{array}{l}45 \\
35 \\
20\end{array}$ & $\begin{array}{l}28 \\
52 \\
20\end{array}$ & 0.037 & NC & $\mathrm{NC}$ \\
\hline Splenic ellipsoid hyalinization & $\begin{array}{c}0 \\
1 \\
1+2\end{array}$ & $\begin{array}{r}9 \\
78 \\
13\end{array}$ & $\begin{array}{l}23 \\
60 \\
17\end{array}$ & 0.013 & $\mathrm{NC}$ & NC \\
\hline VHSV & & $\begin{array}{l}\text { Positive } \\
(n=11)\end{array}$ & $\begin{array}{l}\text { Negative } \\
(\mathrm{n}=200)\end{array}$ & & & \\
\hline Fin base reddening & $\begin{array}{c}0 \\
1 \\
2+3\end{array}$ & $\begin{array}{l}18 \\
36 \\
45\end{array}$ & $\begin{array}{l}50 \\
38 \\
12\end{array}$ & 0.005 & NC & \\
\hline Gastritis, submucosal & $\begin{array}{l}2 \\
3\end{array}$ & $\begin{array}{l}27 \\
73\end{array}$ & $\begin{array}{l}77 \\
23\end{array}$ & $<0.001$ & 9.1 & $2.3,36$ \\
\hline $\begin{array}{l}\text { GiIl arch inflammation or } \\
\text { hematopoiesis }\end{array}$ & $\begin{array}{c}0+1 \\
2\end{array}$ & $\begin{array}{l}45 \\
55\end{array}$ & $\begin{array}{l}83 \\
17\end{array}$ & 0.002 & 5.7 & $1.6,20$ \\
\hline Meningoencephalitis & $\begin{array}{c}0 \\
1+2\end{array}$ & $\begin{array}{l}82 \\
18\end{array}$ & $\begin{array}{r}98 \\
2\end{array}$ & $0.005^{\circ}$ & 8.7 & $1.5,51$ \\
\hline Hepatic focal necrosis & $\begin{array}{c}0 \\
1+2+3\end{array}$ & $\begin{array}{l}82 \\
18\end{array}$ & $\begin{array}{r}98 \\
2\end{array}$ & $0.002^{\circ}$ & 11 & $1.8,68$ \\
\hline $\begin{array}{l}\text { Intestinal arteriolar focal } \\
\text { intimal hyperplasia }\end{array}$ & $\begin{array}{c}0 \\
1+2\end{array}$ & $\begin{array}{l}27 \\
73\end{array}$ & $\begin{array}{l}75 \\
35\end{array}$ & 0.012 & 5.0 & $1.3,19$ \\
\hline Myocardial mineralization & $\begin{array}{l}0 \\
1\end{array}$ & $\begin{array}{l}90 \\
10\end{array}$ & $\begin{array}{r}99 \\
1\end{array}$ & $0.003^{\circ}$ & 22 & $1.3,380$ \\
\hline \multicolumn{4}{|c|}{$\begin{array}{l}\text { Odds ratio is defined as the ratio of the odds of a fish being at one } \\
\text { level of a condition (e.g. having a scorable lesion) as opposed to } \\
\text { being at another level of a condition (e.g. having no lesion) for one } \\
\text { category of a variable (e.g. female or VHSV-positive) to the corre- } \\
\text { sponding odds for the other category of the variable (e.g. male or } \\
\text { VHSV-negative). For example, females were } 58 \text { times more likely } \\
\text { to have pigmented gonadal macrophage aggregates than were } \\
\text { males; fish with mild/moderate iris reddening were } 2 \text { times more } \\
\text { likely to have renal congestion than were fish with no iris redden- }\end{array}$} & \multicolumn{3}{|c|}{$\begin{array}{l}{ }^{\circ} \text {-value. For lesions with minimum expected cell frequency }<1\left({ }^{\circ}\right) \text {, } \\
\text { only comparisons with } p \leq 0.010 \text { were considered significant. Note } \\
\text { that for compansons with a low expected cell frequency, the odds } \\
\text { ratio has a wide confidence interval } \\
\text { "NC: odds ratios were not calculated for lesions with more than } 2 \\
\text { groups (e.g. splenic Ichthyophonus) }\end{array}$} \\
\hline
\end{tabular}




\section{Ichthyophonus hoferi}

All organs contained Ichthyophonus hoferi (hereafter referred to as Ichthyophonus) (Table 1), and the multinucleate resting spore stage was the most common form. Morphology of Ichthyophonus and the host reaction were similar to those reported in infections in Atlantic herring (Daniel 1933b, Sindermann 1970). Most resting spores were surrounded by a rim of fibroblasts and maturing collagenous connective tissue, but some were surrounded by activated macrophages. Severe granulomatous inflammation, common in the heart, was usually associated with developing spores (Fig. 3C). Occasionally, resting spores had burst and released multinucleate endospores (Fig. 4A). A consistent scoring system was used for Ichthyophonus in each organ: score $=0$ (no Ichthyophonus); score $=1$ $(<1$ resting spore per $100 \times$ field $)$; score $=2(\geq 1$ but $<3$ resting spores per $100 \times$ field, but inflammation was limited to a thin rim of fibrous connective tissue); score $=3$ ( $\geq 1$ resting spore per $100 \times$ field, with prominent granulomatous inflammation, or $\geq 3$ resting spores per $100 \times$ field, regardless of the amount of inflammation).

Granulomatous inflammation associated with Ichthyophonus had to be differentiated from other forms of macrophage aggregates. Pigmented macrophage aggregates at least $60 \mu \mathrm{m}$ in diameter were common in liver, spleen, and kidney. Pigment varied from yellowbrown (Fig. 5A, B) to green-brown, but aggregates did not contain melanin. Pigmented macrophage aggregates were more common in older fish, and some aggregates were as large as $300 \mu \mathrm{m}$ in diameter (Fig. 5B). Aggregates of nonpigmented activated macrophages were classified as nonspecific granulomatous inflammation (Fig. 5C). Granulomatous inflammation was composed of activated macrophages with pale eosinophilic cytoplasm. Activated macrophages sometimes infiltrated and expanded foci of pigmented macrophage aggregates. Small numbers of lymphocytes and eosinophilic granular leukocytes were scattered throughout foci of granulomatous inflammation.

Lesions associated with Ichthyophonus occurred in 62 of $212(29 \%)$ fish, but no single organ had greater than $21 \%$ prevalence (Fig. 6). Prevalence of Ichthyophonus in skin and skeletal muscle was the second highest after kidney, but most cases in skin and skeletal muscle were mild ( 31 of $39,79 \%$ ). By comparison, prevalence of Ichthyophonus in the heart was similar to that in skin and skeletal muscle, but relatively few cases in the heart were mild (14 of $38,37 \%$ ).

A sum-Ichthyophonus (sumICH) score was calculated for each fish by adding the individual Ichthyophonus scores from all 10 organs for that particular fish. For example, Ichthyophonus scores in organs of fish \#106 included spleen (score = 2), kidney (score $=1$ ), and a combined score for skin and skeletal muscle (score $=1$ ), but the other 7 organs had no Ichthyophonus (score $=0$ ); therefore, the sumICH score for fish \#106 was 4 . Because the maximum Ichthyophonus score for each organ was 3 (severe), the maximum possible sumICH score for a fish was 30 . The highest actual score was 24. SumICH scores significantly increased with increased severity of several internal lesions, but sumICH scores were not associated with any external lesions. Several lesions were significantly associated with greater sumICH scores: cardiac thrombosis, gastric foreign body, gastric focal parenchymal leukocytes, hepatic eosinophilic granular leukocytes, intestinal foreign body granuloma, intestinal mesenteric steatitis, and skeletal myositis. Note that Levene's test for equality of variances was significant for all comparisons except skeletal myositis.

Association of Ichthyophonus scores with plasma chemistries was variable (Table 1), but AST and CPK, enzymes commonly used in mammalian medicine as part of the evaluation of general health, were significantly associated with Ichthyophonus scores in every organ (univariate ANOVA). Increases in CPK in mammals result from disruption in muscle cell membranes (Willard et al. 1989). By comparison, AST is present in significant quantities in mitochondria of hepatocytes, muscle, erythrocytes, and other blood-rich organs. The most common causes of increased AST in small domestic mammals are hepatic disease, muscular disease (inflammation or necrosis), and hemolysis (Willard et al. 1989).

The significant increase in CPK and AST in every organ was inconsistent with distribution of these enzymes in mammals. Therefore, multiple regression analysis was used to model a multifactor ANOVA, examining the linear relationships between the dependent variable CPK (or AST) and Ichthyophonus lesion scores in 9 organs (brain, gill, heart, intestine, kidney, liver, skin/ skeletal muscle, spleen, and stomach). Gonad scores were not analyzed because only 3 gonads contained Ichthyophonus. For CPK, brain Ichthyophonus status, gender, and gonad weight were the only significant predictors when all organs were included in the multiple regression equation. For AST, renal Ichthyophonus status and gonad weight were the significant predictors; however, in the final model, predicted values for AST decreased when a fish had renal Ichthyophonus.

As a relative measure of the severity of Ichthyophonus in individual organs, a mean sumICH score was computed as follows for each organ: all fish with Ichthyophonus in an organ were selected, their sumICH scores were totaled, and this sum of sumICH scores was divided by the number of fish in which the organ was infected. For example, of 212 kidneys examined, 43 had Ichthyophonus; the mean sumICH 


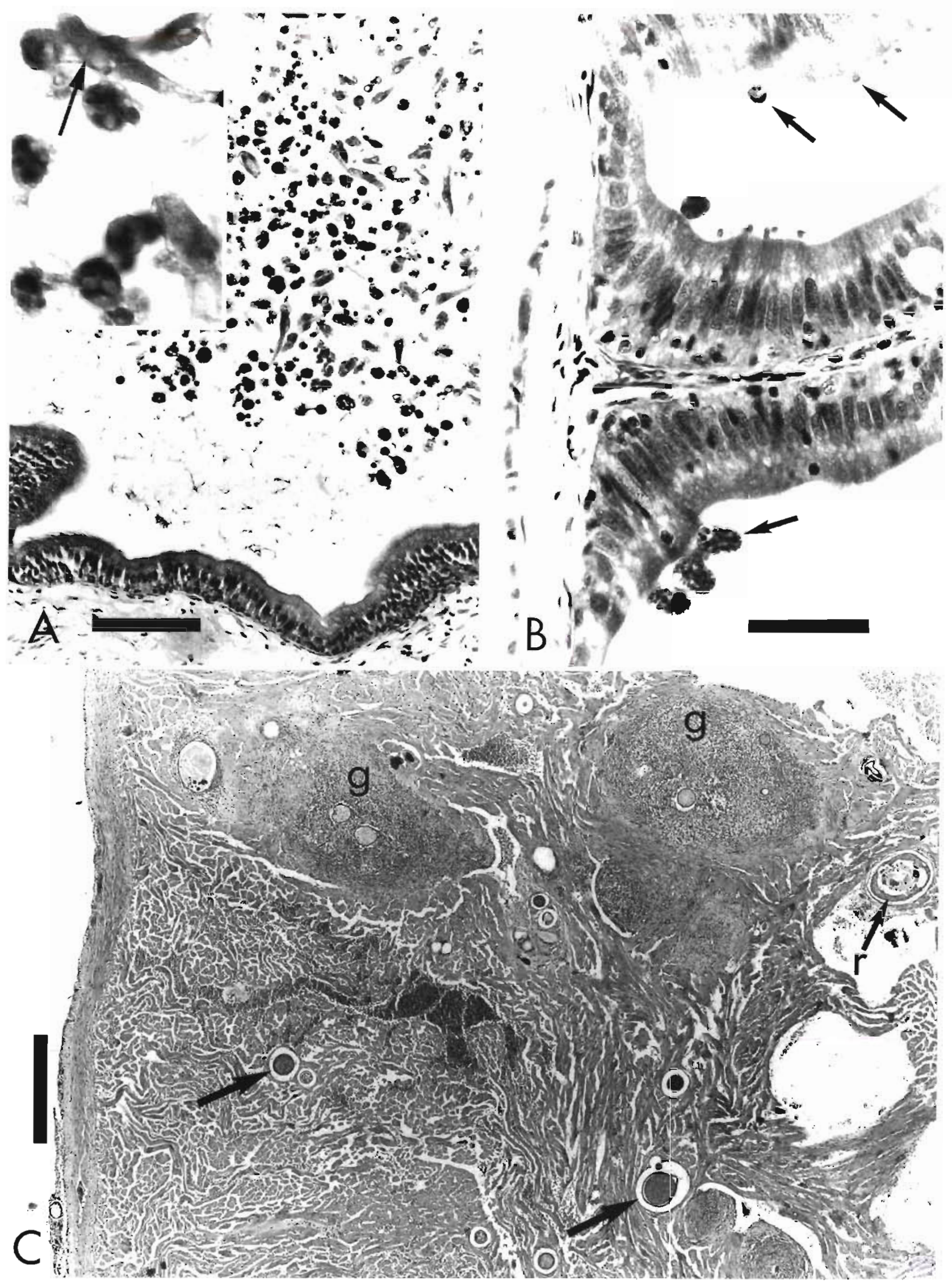


Fig. 3. Clupea pallasi. Internal parasites of Pacific herring sampled from Prince William Sound, Alaska, during spawning, 1994; hematoxylin and eosin stain. (A) The myxosporean Ceratomyxa auerbachi in the gall bladder lumen; despite large numbers of organisms, inflammation in the gall bladder wall is minimal; bar length $=80 \mu \mathrm{m}$. Inset: trophozoites and maturing spores (arrow points to polar capsules); bar in larger print is $30 \mu \mathrm{m}$ long at inset magnification. (B) Several stages of an unclassified coccidian (Goussia $5 \mathrm{p}$.?) in the apical margin of epithelial cells of intestinal cecae. Note different stages of development (arrows) and lack of inflammation; bar length $=30 \mu \mathrm{m}$. (C) Forms of Ichthyophonus in the heart include multinucleate resting spores with minimal inflammation (arrows), remnants of ruptured resting spores ( $r$ ) with small endospores, and developing spores surrounded by severe granulomatous inflammation $(g)$; bar length $=400 \mu \mathrm{m}$

score for those 43 fish was 9.4 ; by comparison, the mean sumICH score for the 17 fish with brain Ichthyophonus was 14.2. Generally, organs with the lowest Ichthyophonus prevalence (e.g. brain) had the highest mean sumICH scores (Fig. 6).

\section{VHSV}

Eleven of 233 Pacific herring (4.7\%) were positive for VHSV. Virus was isolated from 7 of 233 spleenkidney pools and from 5 of 15 skin lesions. One fish had VHSV isolated from both the spleen-kidney pool and a skin lesion. Several lesions and alterations in blood chemistries were associated with VHSV infection (Tables $2 \& 3$ ). Among external lesions, fin base reddening was significantly associated with VHSV infection. Also, VHSV was significantly associated with focal skin reddening $(p=0.03$, chi-square test for homogeneity), but the minimum expected cell frequency was $<1$. The low minimum expected cell frequency resulted from having only 11 positive fish out of 233 fish sampled. Among chemistries, decreased plasma levels of albumin, ALP, and cholesterol were associated with VHSV infection (Table 3). Loss of albumin might have resulted from leakage from external lesions. Albumin was highly correlated with cholesterol $(r=0.895)$ and ALP $(r=0.587)$ regardless of VHSV status.

The normal gastric submucosa contained diffuse infiltrates of large numbers of eosinophilic granular leukocytes, but these cells did not extend into the adjacent muscularis or mucosa (Fig. 2D). Similar infiltrates have been described in intestine of Atlantic herring (Morrison et al. 1986). In 53 Pacific herring, the gastric submucosa also contained small to moderate numbers of lymphocytes and macrophages (Fig. 2E), and these infiltrates were significantly associated with VHSV infection (Table 2).
Sheets of mononuclear cells within gill arches were significantly associated with VHSV infection (Table 2). Gill arches normally contained scattered mononuclear cells that had densely basophilic nuclei and relatively scant basophilic cytoplasm (Fig. 7A). Not all cells could be identified, but they included mature inflammatory cells and hematopoietic cells in various stages of development. In 39 fish, these mononuclear cells were more abundant, but the cells did not alter tissue architecture (Fig. 7B).

Meningoencephalitis was significantly associated with VHSV infection (Table 2), and eosinophilic meningitis was marginally associated with VHSV infection ( $p=0.06$ ). In the brain, meninges usually contained 2 to 25 eosinophilic granular leukocytes in at least one $400 \times$ field, but normal meninges did not contain macrophages or lymphocytes. Forty-two fish had more than 25 eosinophilic granular leukocytes in at least one $400 \times$ field. In 7 fish, the meninges and perivascular space within the neuropile contained foci of inflammation (lymphocytes and macrophages) that were not associated with Ichthyophonus infection, but these foci of meningoencephalitis were $<400 \mu \mathrm{m}$ in diameter in all but one fish.
Table 3. Clupea pallasi. Plasma chemistry values that were significantly different ( $p<0.05$ ) based on status of viral hemorrhagic septicemia virus (VHSV) or gender. Pacific herring were sampled during spawning in Prince William Sound, Alaska, 1994. One-way analysis of variance; for comparisons in which Levene's test for equality of variance was significant $\left({ }^{\circ}\right)$, only comparisons with $p \leq 0.010$ are shown. Plasma chemistries not shown were not significant

\begin{tabular}{|c|c|c|c|c|c|}
\hline Plasma chemistry & Mean & SE & Mean & SE & p-value \\
\hline & \multicolumn{4}{|c|}{ VHSV status } & \\
\hline & \multicolumn{2}{|c|}{ Negative $(\mathrm{n}=222)$} & \multicolumn{3}{|c|}{ Positive $(\mathrm{n}=11)$} \\
\hline Albumin $\left(\mathrm{g} \mathrm{dl}^{-1}\right)$ & 0.52 & 0.01 & 0.36 & 0.05 & 0.007 \\
\hline $\operatorname{ALP}\left(\mathrm{U} \mathrm{l}^{-1}\right)$ & 56.1 & 1.4 & 36.6 & 4.5 & 0.002 \\
\hline \multirow[t]{3}{*}{ Cholesterol $\left(\mathrm{mg} \mathrm{dl}^{-1}\right)$} & 221.4 & 4.7 & 156.9 & 21.0 & 0.003 \\
\hline & \multicolumn{4}{|c|}{ Gender } & \\
\hline & \multicolumn{2}{|c|}{ Female $(n=117)$} & \multicolumn{3}{|c|}{ Male $(n=116)$} \\
\hline Albumin $\left(\mathrm{g} \mathrm{dl}^{-1}\right)$ & 0.47 & 0.02 & 0.56 & 0.02 & $<0.001$ \\
\hline $\operatorname{ALP}\left(\mathrm{U} \mathrm{I}^{-1}\right)$ & 59.3 & 2.1 & 51.1 & 1.6 & 0.002 \\
\hline Chloride (mmol l-1) & 160.4 & 0.9 & 165.6 & 1.2 & $0.001^{\circ}$ \\
\hline Cholesterol (mg dl${ }^{-1}$ ) & 202.1 & 6.3 & 234.8 & 6.6 & $<0.001$ \\
\hline $\mathrm{CO}_{2}\left(\mathrm{mmol} \mathrm{l}^{-1}\right)$ & 5.6 & 0.2 & 6.5 & 0.2 & 0.004 \\
\hline Glucose $\left(\mathrm{mg} \mathrm{dl}^{-1}\right)$ & 75.9 & 2.6 & 90.0 & 4.3 & 0.001 \\
\hline Potassium (mmol $\left.\mathrm{I}^{-1}\right)$ & 2.13 & 0.10 & 2.45 & 0.11 & 0.029 \\
\hline Total protein $\left(g \mathrm{dl}^{-1}\right)$ & 2.14 & 0.06 & 2.30 & 0.05 & 0.042 \\
\hline
\end{tabular}




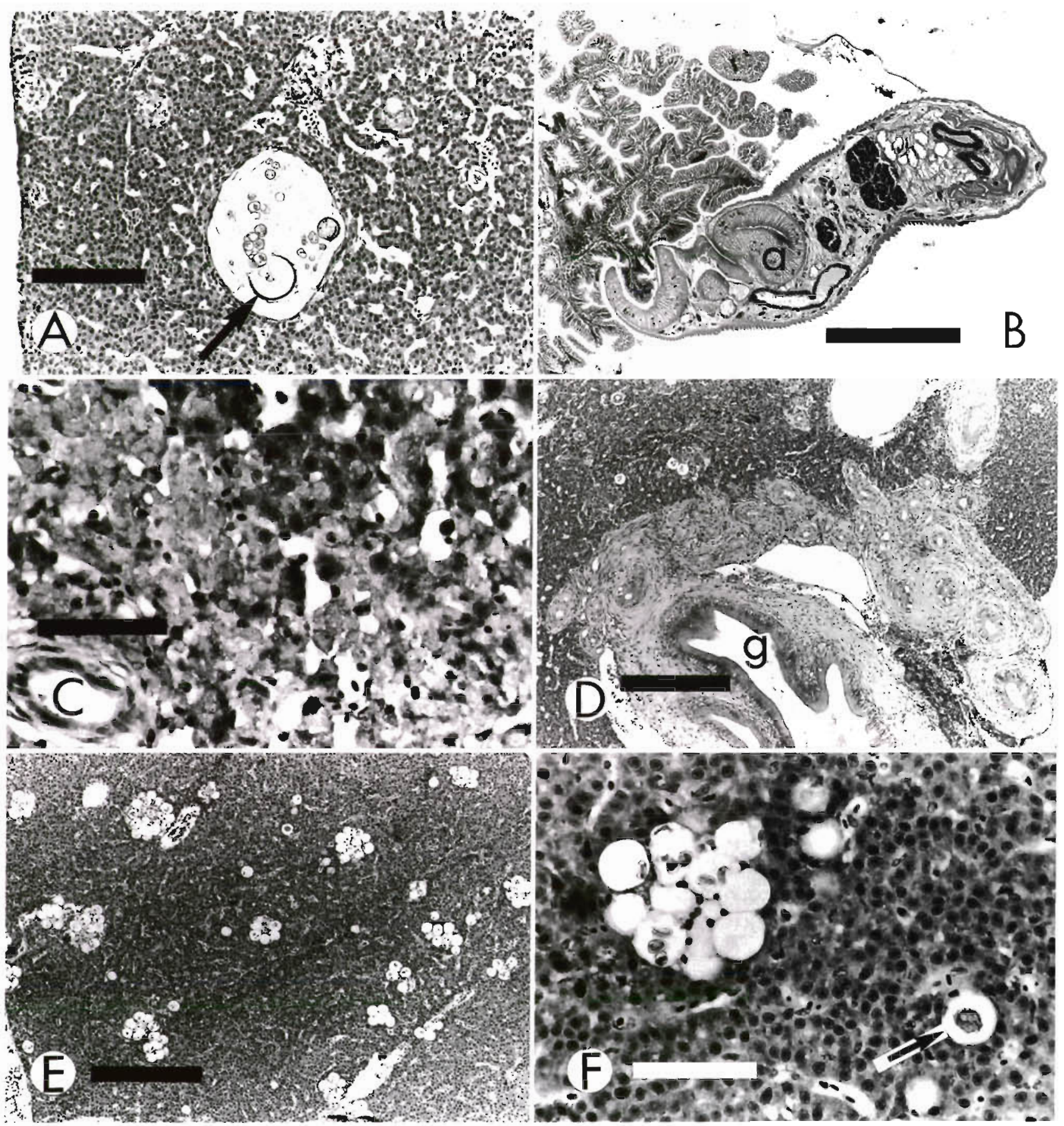

Fig. 4. Clupea pallasi. Microscopic lesions in the liver and stomach of Pacific herring sampled from Prince William Sound, Alaska, during spawning, 1994; hematoxylin and eosin stain. (A) Liver with a ruptured Ichthyophonus resting spore (arrow) that has released several multinucleate endospores; bar length $=100 \mu \mathrm{m}$. (B) Trematode (probably Hemiuridae) attached to the gastric mucosa with an oral sucker. Note the prominent acetabulum (a); bar length $=300 \mu \mathrm{m}$. (C) Hepatic coagulative necrosis; note pyknosis and karyolysis within a broad band of hepatocytes; bar length $=40 \mu \mathrm{m}$. (D) Biliary hyperplasia at the base of the gall bladder $(\mathrm{g})$; bar length $=$ $200 \mu \mathrm{m}$. (E) Multiple foci of Goussia clupearum scattered throughout the hepatic parenchyma; bar length $=200 \mu \mathrm{m}$. (F) Sporulated oocysts and an unsporulated oocyst (arrow) of Goussia clupearum in the liver. Note minimal inflammation; bar length $=50 \mu \mathrm{m}$

Fig. 5. Clupea pallasi. Normal liver histology and hepatic lesions in Pacific herring sampled from Prince William Sound, Alaska, during spawning, 1994; hematoxylin and eosin stain. (A) A small pigmented macrophage aggregate (arrow); bar length = $150 \mu \mathrm{m}$. (B) A large pigmented macrophage aggregate; magnification same as (A). (C) Two foci of granulomatous inflammation (arrows) that were unrelated to Ichthyophonus. Note that pale foci of activated macrophages contain scattered lymphocytes but pigment is minimal; magnification same as (A). (D) Severe, acute, zonal, coagulative necrosis with small irregular foci of viable hepatocytes (e.g. v and arrows); magnification same as (A). (E) Severe single cell hepatocellular necrosis (apoptosis). Several hepatocytes have condensed nuclei with contracted hypereosinophilic cytoplasm (arrows); bar length $=30 \mu \mathrm{m}$ 


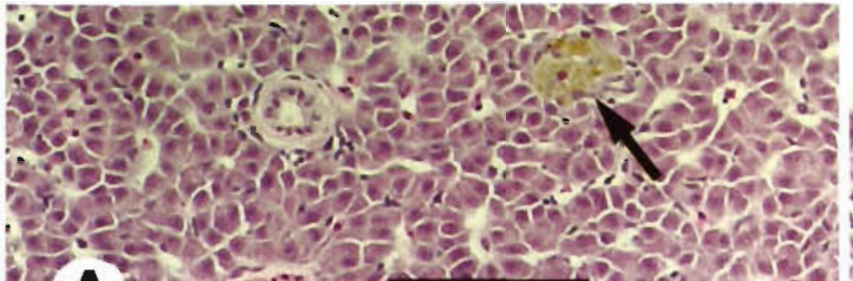

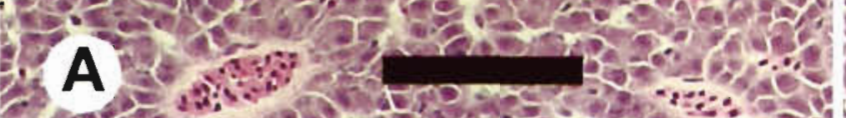
Quber ats

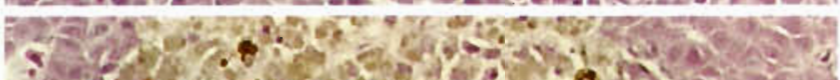

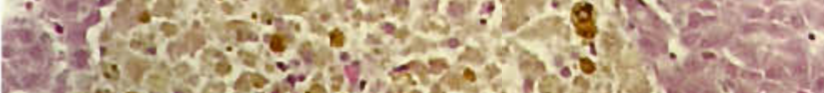

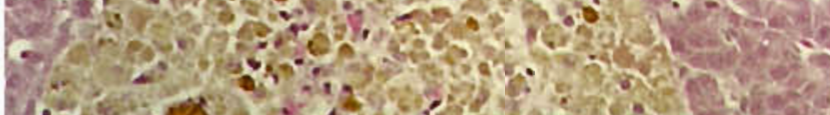

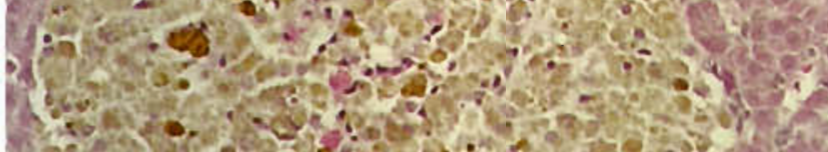

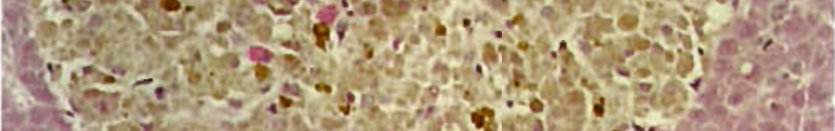

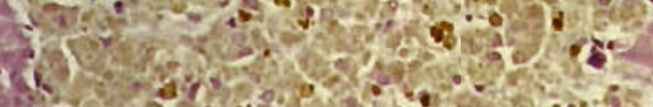

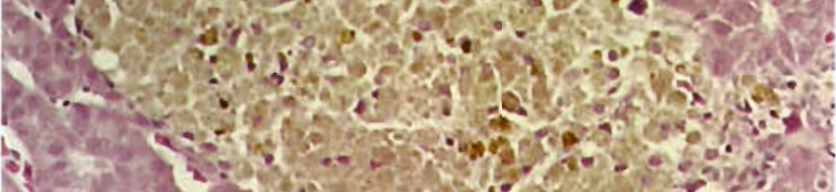

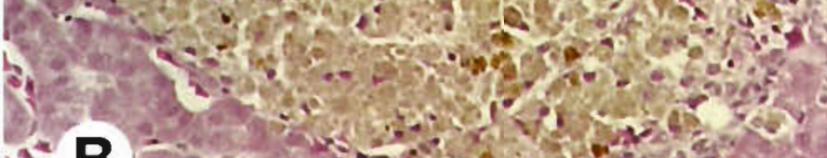
A
A.

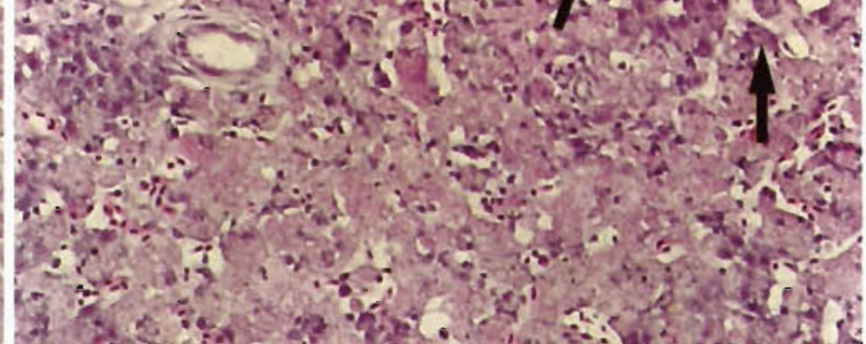

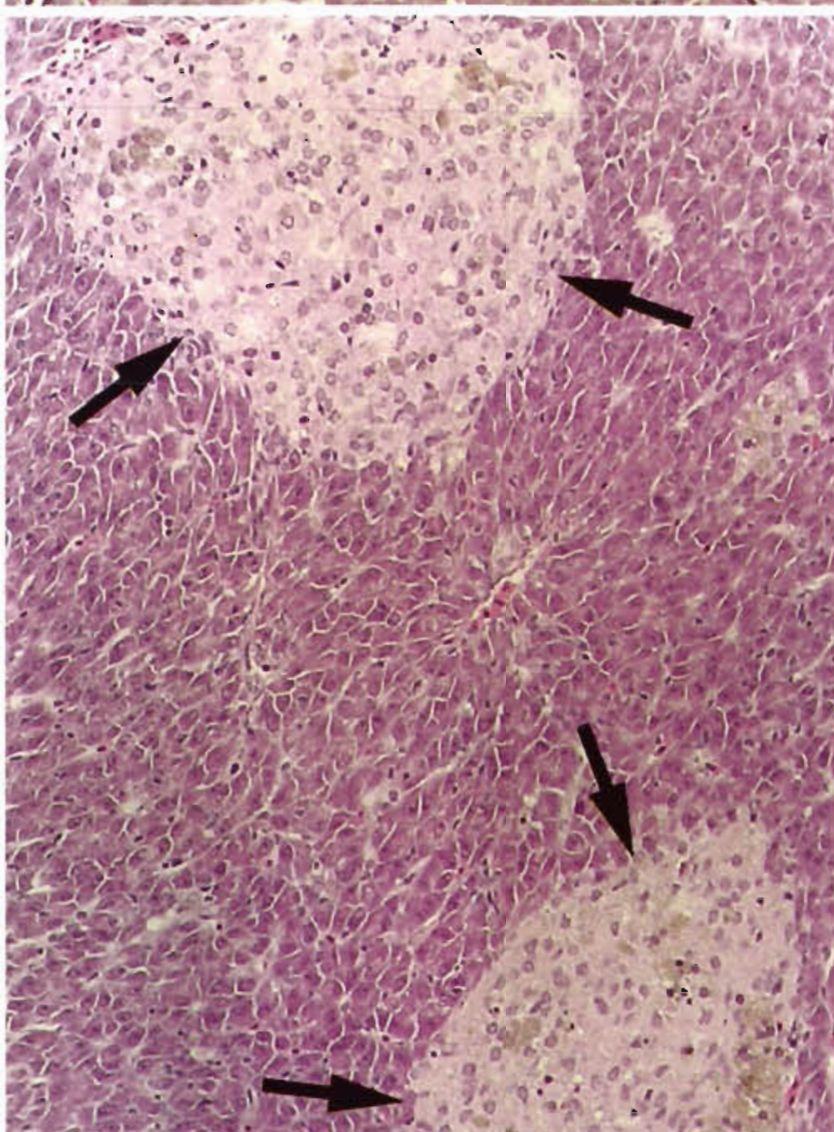
to 0 on

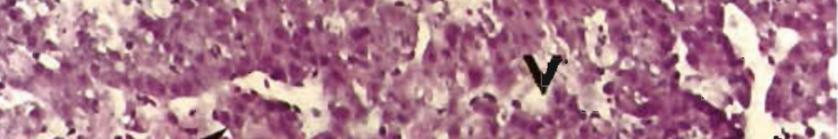

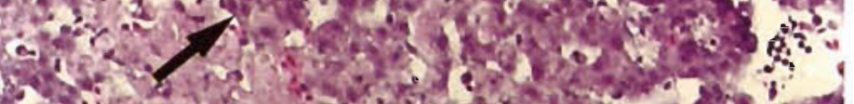

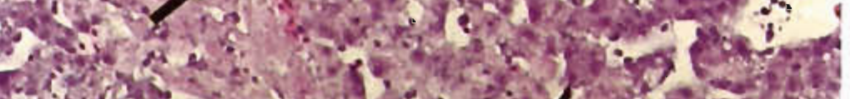

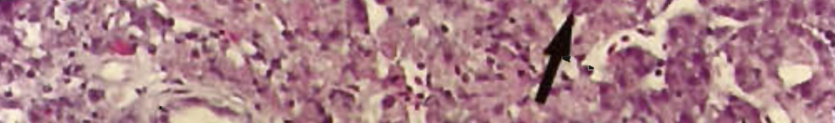

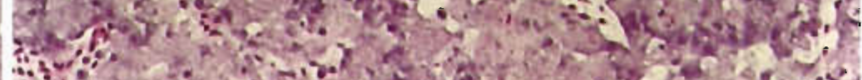

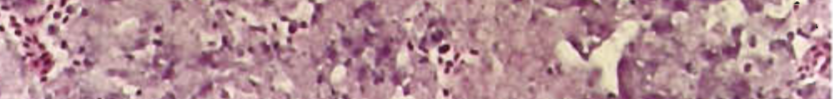

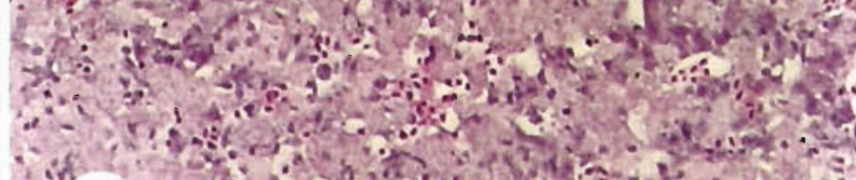

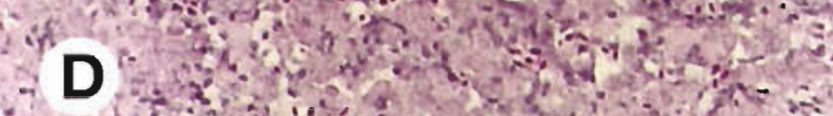

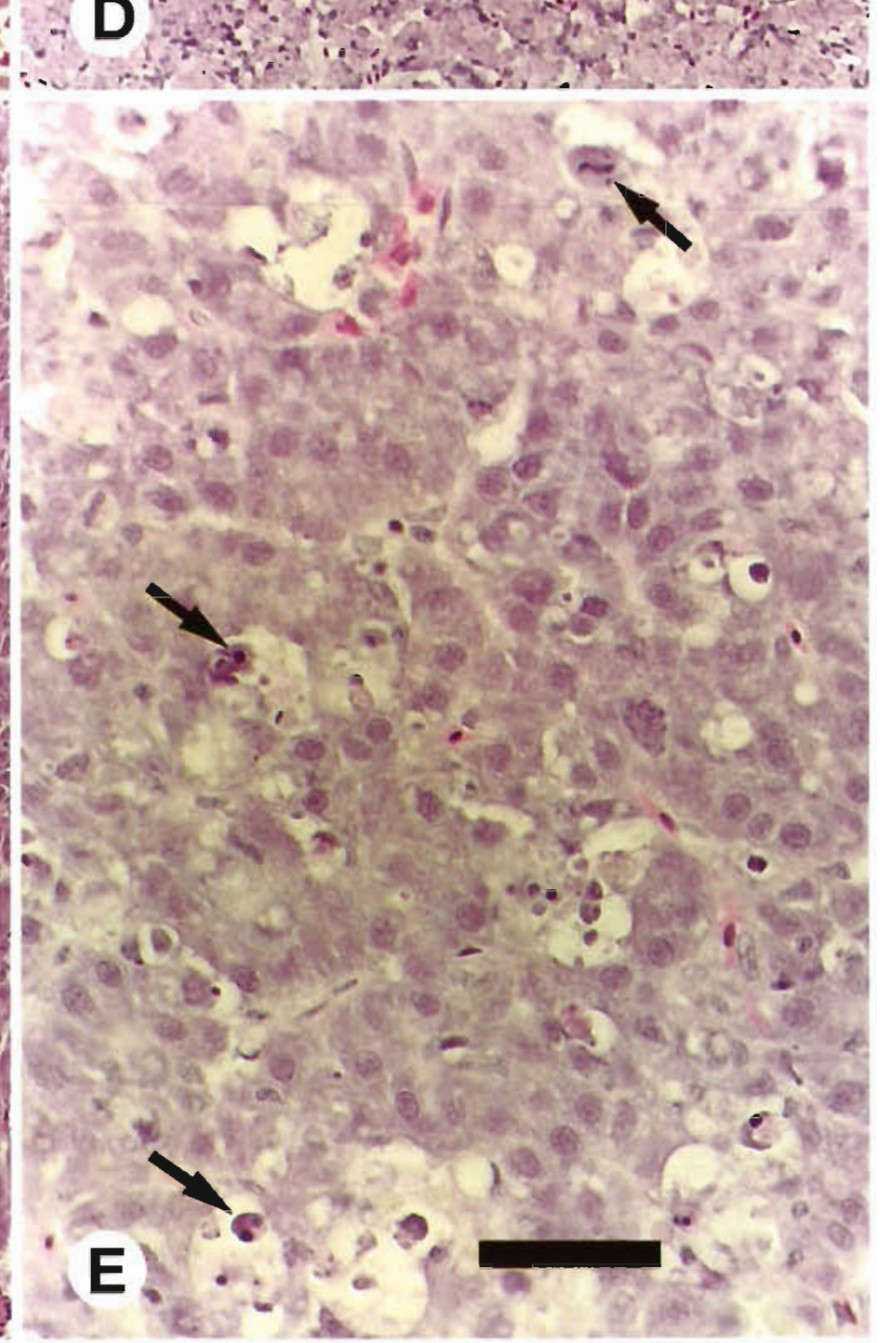




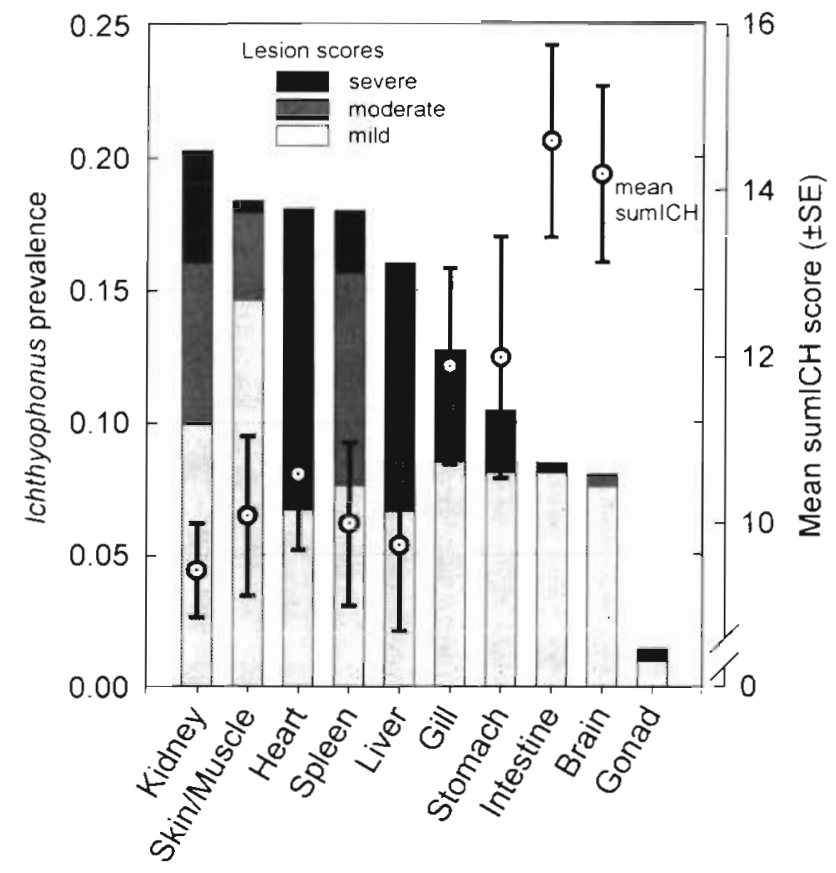

Fig. 6. Clupea pallasi. Sample prevalence of IChthyophonus lesion scores in various organs compared with mean sumIchthyophonus (mean sumICH) score for each organ. Lesions were scored as none (0), mild (1), moderate (2), or severe (3), and the sumICH score was calculated for each fish by adding the Ichthyophonus score for all organs in that fish. The mean sumICH score was calculated for each organ. For example, the mean sumiCH score for the brain was the average of sumICH scores for all 17 fish that had brain Ichthyophonus; fish without brain Ichthyophonus were not used for calculations of the mean sumiCH score for the brain. Sample size varies from 210 to 212

Focal hepatic necrosis was not common (6 fish affected) but was significantly associated with VHSV infection (Table 2). Broad bands of affected hepatocytes had hypereosinophilic cytoplasm and pyknotic, karyorrhectic, or karyolytic nuclei characteristic of coagulative necrosis (Figs. 4C \& 5D). By comparison, single cell hepatocellular necrosis was more common (16 fish affected) but was not significantly associated with VHSV infection. Individual necrotic (or apoptotic) cells had condensed hypereosinophilic cytoplasm and pyknotic nuclei. Necrotic (or apoptotic) cells were often surrounded by a pericellular clear space (Fig. 5E).

Focal intimal hyperplasia of arteriolar walls was relatively common and was scored in sections of intestine, skin and skeletal muscle, and spleen. In the intestine only, this lesion was significantly associated with VHSV infection (Table 2). Normal arteries and arterioles had a smooth intimal surface without valves (Fig. 7C). In some cases, however, the intima contained one or more foci of connective tissue that projected into the lumen from a narrow base in mild cases, and from a broad base in moderate cases (Fig. 7D). The origin of these foci is unknown, but they may have been sequella to endothelial damage.

\section{Gender-associated lesions}

Lesions significantly more frequent in ovaries included hyalinization of vessel walls and pigmented macrophage aggregates. By comparison, granulomatous inflammation was significantly more common in testes than in ovaries (Table 2). Except for one female with severe ovarian Ichthyophonus, germ cells were mature in all fish and lesions were not severe enough to have impaired spawning.

Gender differences were significant for several nongonadal lesions (Table 2). Myxosporeans in the gall bladder (Ceratomyxa auerbachi) were significantly more frequent in females. Males had a significantly greater frequency of severe intestinal mesenteric steatitis, renal proximal tubular epithelial vacuolation, and renal tubular dilation. Splenic Ichthyophonus prevalence was similar in males and females, but associated lesions were more likely to be severe in females. Isolation of VHSV was more frequent from males ( 7 of 116) than from females (4 of 117 ), but differences were not significant (chi-square test, $2 \times 2$ contingency table).

Fig. 7 Clupea pallasi. Microscopic lesions in various organs of Pacific herring sampled from Prince William Sound, Alaska, during spawning. 1994; hematoxylin and eosin stain. (A) and (B) Gill arches normally contained scattered inflammatory or hematopoietic cells (A), but some fish had more abundant inflammatory or hematopoietic cells (B); same magnification, bar length $=100 \mathrm{~m}$. (C) and (D) Small arteries and nerves were common near exocrine pancreatic tissue between intestinal cecae. Normal arteries (a) had a smooth intimal surface (C), but arteries in some fish had focal intimal hyperplasia (D) that varied from mild (f and arrow) to moderate (arrowheads); same magnification, bar length $=150 \mathrm{~m}$. (E) and (F) Intestinal mesenteries normally had mild infiltrates of inflammatory cells and moderately sized adipocytes (E), but some fish had moderate infiltrates of inflammatory cells (steatitis) and atrophied adipocytes $(\mathrm{F})$; same magnification, bar length $=40 \mathrm{~m}$. $(\mathrm{G})$ and $(\mathrm{H})$ Renal archinephric ducts contained intraluminal parasites, but associated inflammation was minimal. Pansporoblasts of the myxosporean Ortholinea orientalis (G, arrow) were free within the lumen, whereas unidentified myxosporeans $(\mathrm{H}$, arrow) were smaller and adhered to the luminal epithelium; same magnification, bar length $=40 \mathrm{~m}$ 


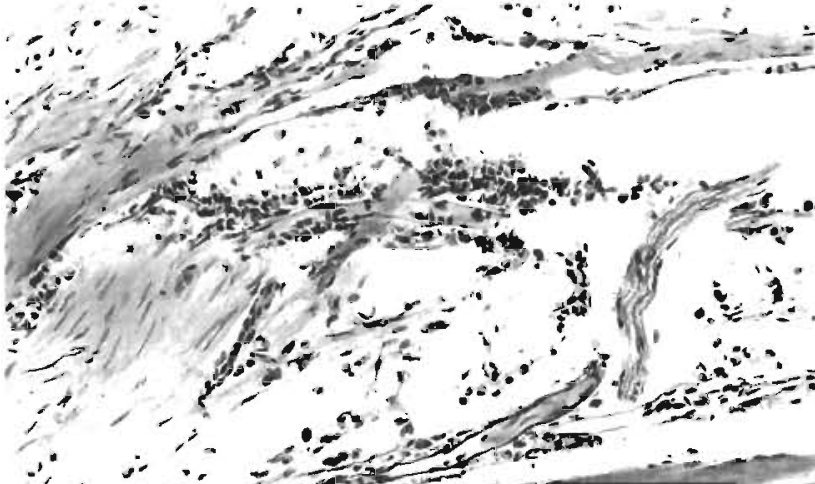

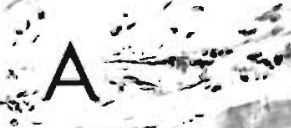

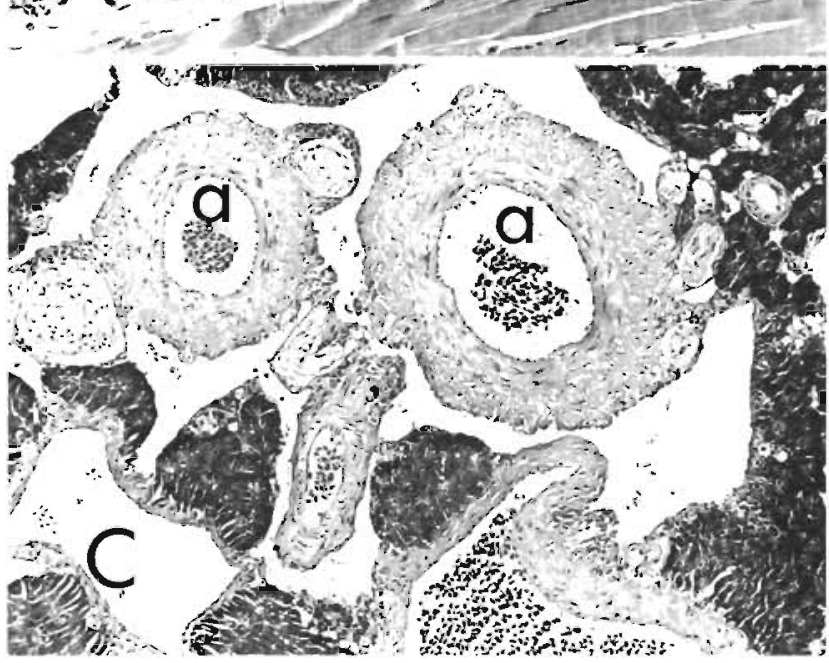

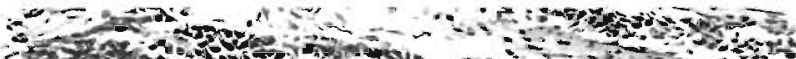

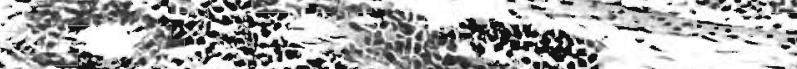

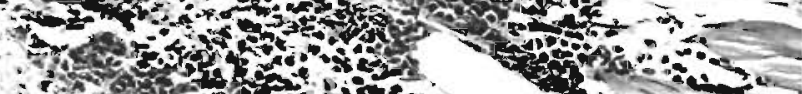

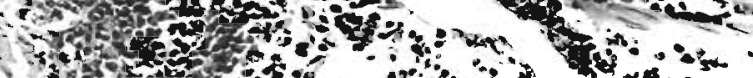
- 10 on

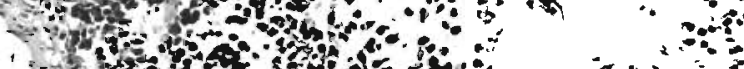

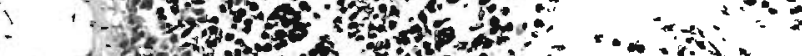

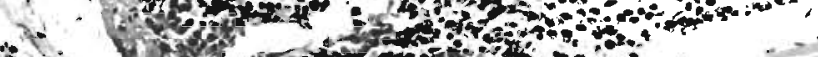
$\mathrm{B}$ Q

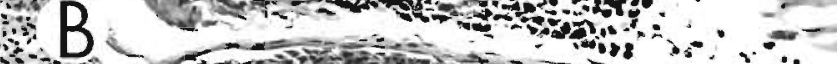
H.
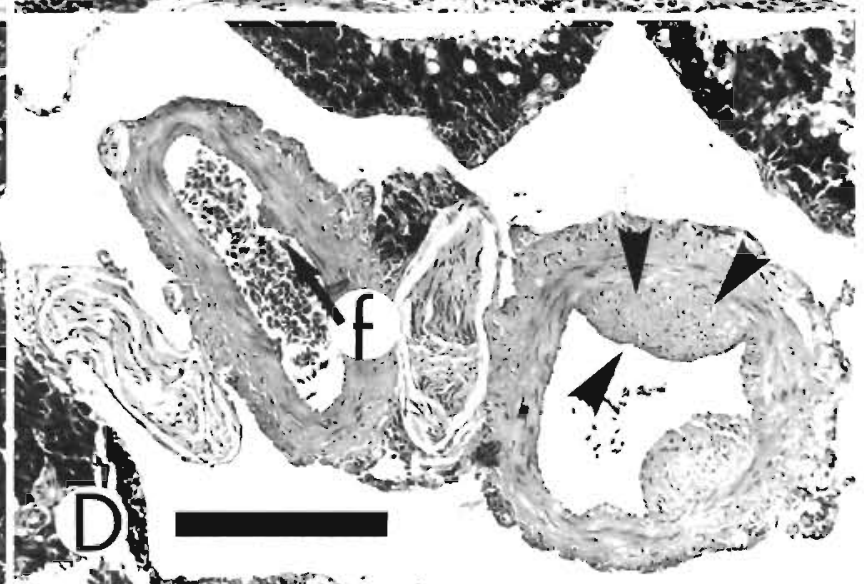
3.

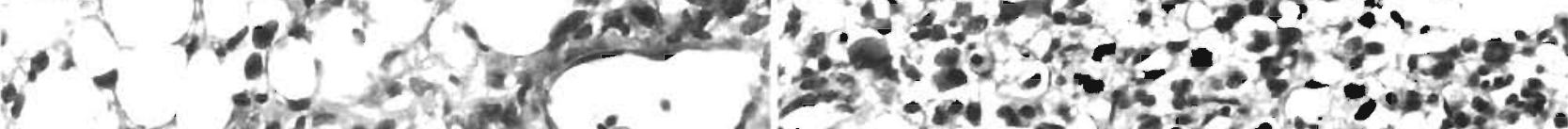

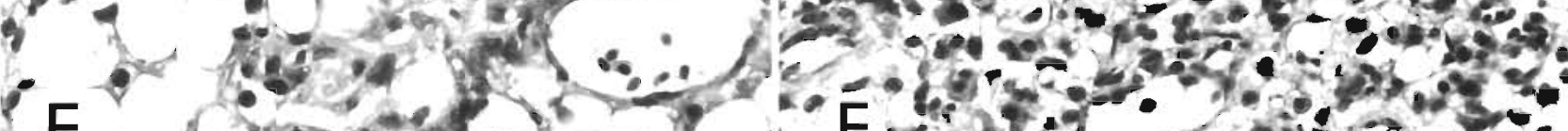

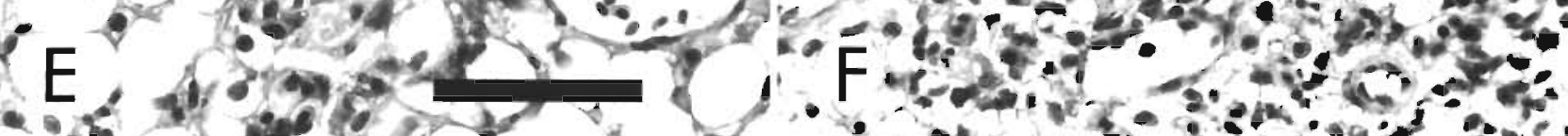

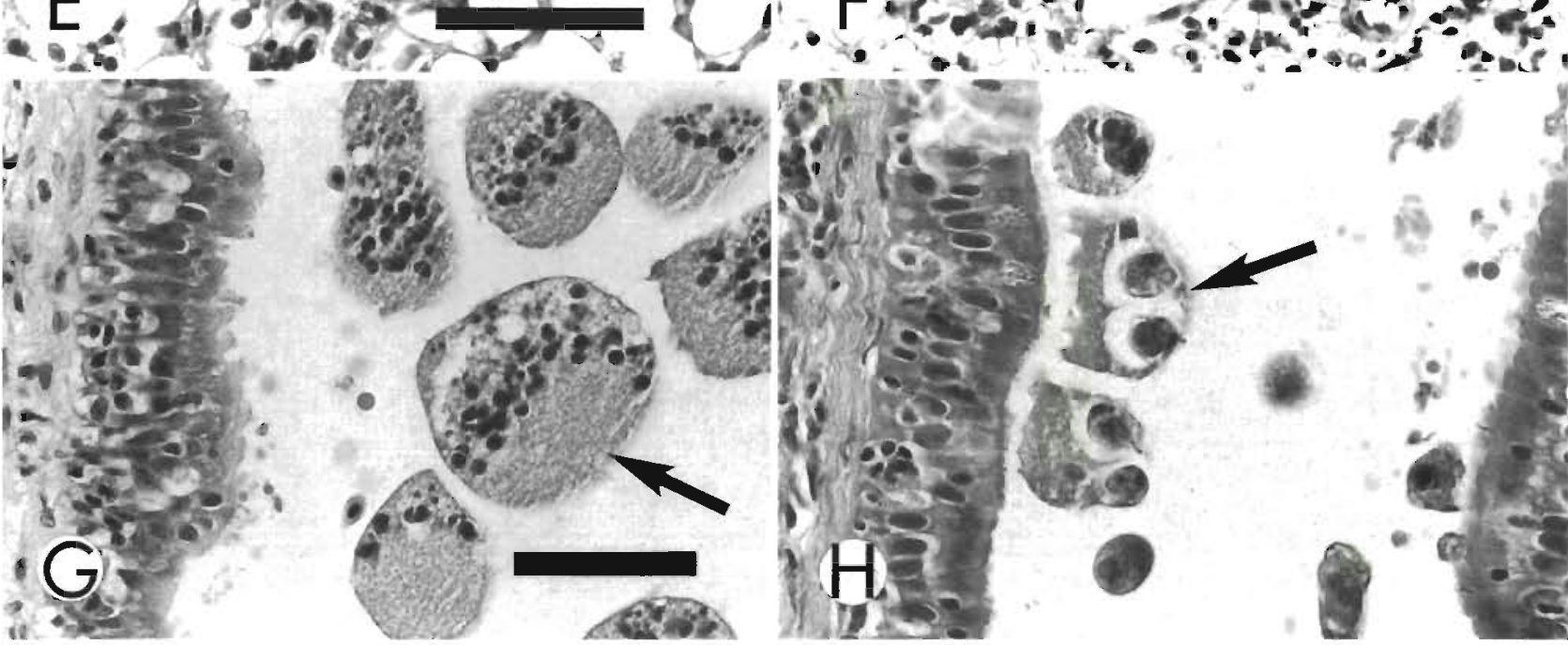


Intestinal mesenteric steatitis involved peritoneal fat throughout the mesenteries of the viscera. Lipid volume of adipocytes varied from moderately abundant to minimal. In moderate cases of steatitis, lipid volume was often less than the volume of adipocyte nuclei (Fig. 7F). Inflammatory infiltrates included macrophages, lymphocytes, and eosinophilic granular leukocytes. All fish had at least some inflammatory cells within the peritoneal fat (Fig. $7 \mathrm{E}$ ), but 19 males and 8 females had more than $30 \%$ of the volume of peritoneal fat infiltrated by inflammatory cells. The cause of these inflammatory infiltrates was not determined.

Proximal renal tubular epithelium was considered vacuolated if intracytoplasmic clear spaces were larger than adjacent nuclei. Kidneys from 9 males and 1 female contained vacuolated tubular epithelial cells, but in only one case (a male) were more than $20 \%$ of the proximal tubular epithelial cells affected. Renal tubules were considered dilated when luminal diameter was more than twice the thickness of tubular epithelial cells. Kidneys from 7 males and 1 female contained dilated tubules, but in no cases were more than $50 \%$ of the tubules dilated. Causes for these tubular changes are unknown. Although pansporoblasts of the renal myxosporean Ortholinea orientalis sometimes nearly filled archinephric ducts (Fig. 7G), only one of 44 cases was associated with dilated tubules, i.e. Ortholinea orientalis was not associated with dilated tubules.

In addition to these lesions, gender differences were significant for several plasma chemistries (Table 3). Compared to males, females had significantly lower values for albumin, chloride, cholesterol, $\mathrm{CO}_{2}$, glucose, potassium, and total protein, and significantly higher values for ALP. Gender differences were not significant for other plasma chemistries.

\section{Intraperitoneal herring worms (Anisakidae)}

All 233 Pacific herring contained larval parasites of the family Anisakidae within their peritoneal cavities. No attempt was made to differentiate species (e.g. Anisakis vs Contracecum), and parasite morphology and inflammatory response were consistent with previous descriptions (Hauck \& May 1977). Herring worm numbers were significantly greater in females than in males, and numbers significantly increased with increasing severity of several lesions. For example, fish with more severe hepatic cholangitis or biliary hyperplasia (Fig. 4D) had increased numbers of herring worms. Also, increased numbers of intraperitoneal Anisakidae were associated with increased scores for Anisakidae in the liver, intestine, and skeletal muscle. Fish with renal interstitial cell necrosis had fewer herring worms than did fish without renal interstitial cell necrosis.

\section{Lymphocystis virus}

Two Pacific herring had internal lesions consistent with lymphocystis virus, but the skin of these fish was normal. Affected fish had 1 or 2 spherical, white foci, each about $2 \mathrm{~mm}$ in diameter. One focus was in the cranial part of the peritoneal cavity, and the other focus expanded the intestinal mesenteries. Histologically, each white focus was composed of a single hypertrophic fibroblast. The affected fibroblast had a multilayered, $12 \mu \mathrm{m}$ thick, hyaline capsule, with abundant granular basophilic cytoplasm, and a large nucleus (500 $\mathrm{\mu m}$ in diameter) with vacuolated and marginated chromatin (Fig. 8A, B). The infected fibroblast was not associated with any inflammatory cells. Ultrastructurally, the cytoplasm contained abundant icosahedral viral particles, each about $200 \mathrm{~nm}$ in diameter, with an electron-dense viroplasm (Fig. 8C). The ultrastructural features of the virus are characteristic of lymphocystis virus.

\section{Other potential pathogens}

No significant bacterial pathogens were isolated, and none of the blood smears had evidence of VEN. Ulcers often contained variable amounts of granulation tissue with a surface layer of filamentous bacteria; however, culture results indicated that the bacteria had not spread to the kidney.

Pacific herring had 12 other parasites, most of which were associated with few lesions. These parasites in descending order of prevalence included: (1) an intestinal coccidian (Goussia sp.?) that has not previously been described, 91\%; (2) a coccidian in the liver, Goussia (Eimeria) clupearum, 61\%; (3) a testicular coccidian, $57 \%$ of males; (4) a myxosporean in renal tubules, Ortholinea orientalis, $19 \%$; (5) a myxosporean in the gall bladder, Ceratomyxa auerbachi, 19\%; (6) branchial monogenetic trematodes Gyrodactylus spp., 13\%; (7) branchial ciliated protozoans, probably Trichodina and Cryptokaryon spp., 12\%; (8) unclassified renal intraductal myxosporean (?), $11 \%$; (9) branchial Epitheliocystis, $10 \%$; (10) gastric intraluminal trematodes, e.g. Hemiuridae, $8.6 \%$; (11) intestinal trematodes, e.g. Lecithaster gibbosus, $2.9 \%$; and (12) intestinal cestodes, $2.4 \%$. Infestation with these branchial and gastrointestinal parasites did not significantly alter plasma chemistry values or inflammatory changes.

Morphologic features and distribution of the intestinal coccidian were very similar to descriptions of Goussia zarnowskii in the 3-spined stickleback Gasterosteus 

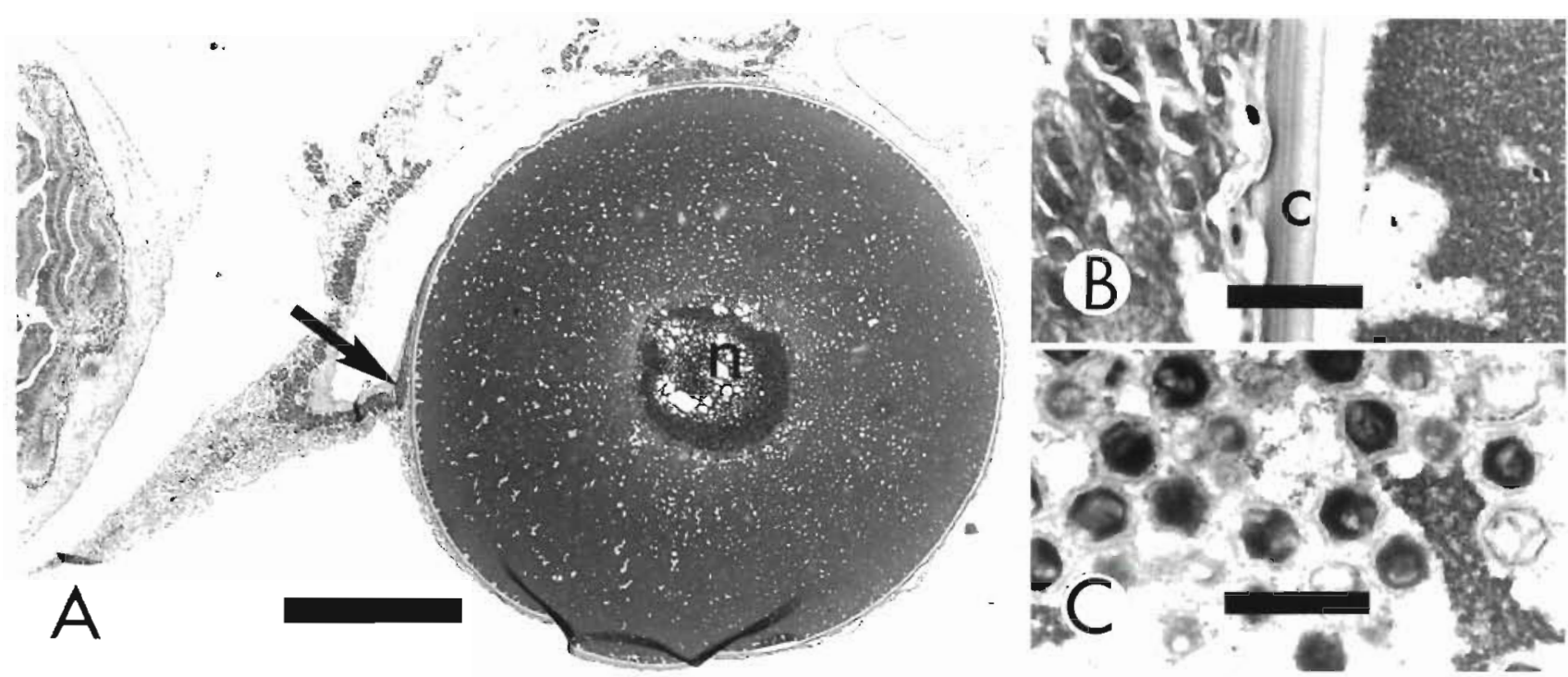

Fig. 8. Clupea pallasi. Lymphocystis virus in a spawning Pacific herring from Prince William Sound, Alaska, 1994. (A) intestine (left) and hypertrophied fibroblast expanding intestinal mesenteries (arrow); note hypertrophic fibroblast nucleus ( $\mathrm{n}$ ); arrow = margin of hypertrophic fibroblast and area shown in detail in (B); bar length $=600 \mu \mathrm{m}$. (B) Multilayered hyaline cell membrane (c) of hypertrophied fibroblast; atrophic exocrine pancreas is on the left and the expanded granular basophilic cytoplasm is on the right; bar length $=25 \mu \mathrm{m}$. (C) Transmission electron micrograph of the cytoplasm of the hypertrophic fibroblast; note icosahedral viral particles; bar length $=0.5 \mu \mathrm{m}$

aculeatus (Jastrzebski \& Komorowski 1990). In Pacific herring, the coccidians were common in small numbers throughout the intestine, including the intestinal cecae Only 2 fish had more than 15 organisms per $400 \times$ field in several fields examined. In affected intestines, the surface of epithelial cells contained spherical to ovoid, basophilic organisms (Fig. 3B). Small forms of the parasite, about $8 \mu \mathrm{m}$ in diameter and densely basophilic, were probably meronts or trophozoites. By comparison, larger forms of the organism, up to $15 \mu \mathrm{m}$ in diameter and $20 \mu \mathrm{m}$ long, were less intensely stained. Some contained densely basophilic 1 to $2 \mu \mathrm{m}$ diameter spherical structures, whereas others contained eosinophilic granules that were 2 to $4 \mu \mathrm{m}$ in diameter. The larger forms were probably microgamonts or microgametes. Oocysts were not present, and there was no inflammatory response to the forms that were present. Also, infections did not significantly alter plasma chemistry values.

Morphologic features and distribution of the hepatic coccidian were very similar to descriptions of Goussia clupearum in Atlantic herring (Morrison \& Hawkins 1984). In Pacific herring, sporulated oocysts (about $18 \times$ $12 \mu \mathrm{m}$ ) were the most abundant stage and were often in small clusters of 2 to 10 organisms (Fig. 4E), whereas unsporulated oocysts (about $35 \mu \mathrm{m}$ in diameter) were rare and usually solitary (Fig. 4F). Severity scores were based almost entirely on numbers of foci of sporulated oocysts per $100 \times$ field: score $=0$ (no parasites); score $=$ $1(\leq 2$ foci $) ;$ score $=2$ (>2 but $\leq 6$ foci $) ;$ and score $=3$ (>6 foci). Despite the relatively large volume of hepatic parenchyma displaced by the parasites in severe cases, inflammation was minimal and severity of infestation was not significantly associated with changes in plasma chemistry values.

Diagnosis of the renal tubular myxosporean Ortholinea orientalis was less sensitive by histopathology $(12$ of $212,5.7 \%)$ than by examination of kidney touch preparations ( 41 of $229,18 \%$ ). However, 3 cases diagnosed on histopathology were not diagnosed on touch preparations, resulting in a combined total prevalence of $19 \%$. Pansporoblasts, the most common form, were roughly spherical, 60 to $80 \mu \mathrm{m}$ in diameter, and were free in the lumen of the archinephric duct (Fig. 7G). Multiple nuclei within the pansporoblast were eccentric or polar, depending on the plane of section. Another parasite, an unidentified myxosporean (?), was in the archinephric duct of 24 fish. The parasites were multicellular and usually attached to the surface of ductular epithelial cells (Fig. 7H). They were 25 to $40 \mu \mathrm{m}$ wide and 15 to $30 \mu \mathrm{m}$ high.

For the renal myxosporean Ortholinea orientalis, the 5 most severely affected fish had plasma calcium levels significantly higher than other groups $(p<0.001$, with significant Levene's test). The mean \pm SE calcium value for the 5 most severely affected fish was $15.3 \pm 2.0 \mathrm{mg}$ $\mathrm{dl}^{-1}$, whereas mean calcium values for groups of fish that were less severely affected ranged from $10.8 \pm 0.4$ to $11.7 \pm 0.14 \mathrm{mg} \mathrm{dl}^{-1}$. The proportion of fish with Ortholinea orientalis infection was significantly higher in fish with renal Ichthyophonus (chi-square test for 
homogeneity). Infection with the renal intraductal parasite (probably a myxosporean) was not significantly associated with any changes in plasma chemistries or any other renal lesions.

The gall bladder sometimes contained large numbers of the myxosporean Ceratomyxa auerbachi (Fig. 3A). Most common were forms that were roughly spherical, multicellular, and 15 to $30 \mu \mathrm{m}$ in diameter with 1 to 6 nuclei. Less common were spindle-shaped forms that were 50 to $80 \mu \mathrm{m}$ long, 15 to $20 \mu \mathrm{m}$ in diameter, and had pale eosinophilic to vacuolated cytoplasm. Sections of the elongate structures often contained 1 or 2 spherical structures (spores?), about $7 \mu \mathrm{m}$ in diameter, that stained intensely eosinophilic. Severe infestations sometimes had mild mononuclear inflammation in the lamina propria of the gall biadder, but infestations were not significantly associated with liver lesions or with changes in plasma chemistries.

\section{Age-associated changes}

The most consistent age-related change was increased severity of pigmented macrophage aggregates in older fish. Indeed, age-related changes were significant in all organs in which pigmented macrophage aggregates were scored: exocrine pancreas, liver, ovary, spleen, and trunk kidney (Table 1). Lesion scores that significantly increased with age included meningoencephalitis, epicarditis, renal tubular epithelial vacuolation, pancreatic zymogen granule depletion, and splenic ellipsoid hyalinization (Table 1). Interestingly, in the liver, scores for increased granulomatous inflammation were significantly associated with decreased age.

Among common parasites, Ichthyophonus, Goussia clupearum, and Ortholinea orientalis were not significantly associated with age (chi-square test for homogeneity). By comparison, Ceratomyxa auerbachi was significantly more frequent in older fish, and the renal intraductal parasite was more common in younger fish (Fig. 9). The number of positive VHSV cases was too small for statistical analysis of age distribution, but the 11 positive cases were distributed among two 3-yrolds, three 4-yr-olds, three 6-yr-olds, one 9-yr-old, and two 10-yr-olds. In general, VHSV-positive cases were over-represented in younger and older fish in the sample; for example, the 1988 year class ( 6 -yr-old fish) comprised $60 \%$ of the sample but only $27 \%$ of the VHSV-positive cases.

\section{Plasma chemistries}

As hold time increased, plasma potassium and $\mathrm{CO}_{2}$ significantly increased, but plasma glucose signifi-
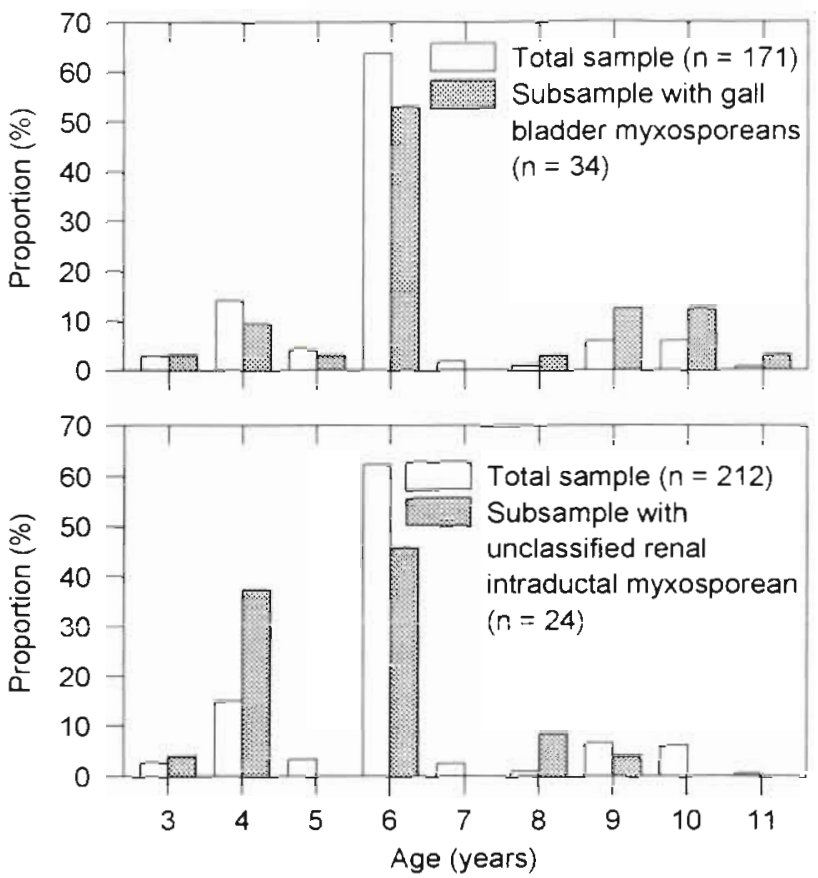

Fig. 9. Clupea pallasi. Age composition of Pacific herring with common parasites compared with the age composition of the sample. Pacific herring were sampled from. Prince William Sound, Alaska, during spawning, 1994. Top: intraluminal gall bladder myxosporean (Ceratomyxa auerbachi). Bottom: unclassified renal intraductal myxosporean

cantly decreased (Table 4). Changes in several other plasma chemistries were not as significant in relation to hold time $\{|r|<0.25)$. A complicating factor was that hold time was significantly longer on the last day of sampling when most fish had completed spawning. Therefore, many of the marginally significant changes might have been related to spawning condition rather than hold time. For example, using multifactor regression, hold time was not a significant predictor of albumin levels even though their values were significantly correlated in univariate analysis.

Among enzymes, AST and CPK values were most variable, and differences in lesion scores (particularly Ichthyophonus) could be discerned on the basis of AST and CPK (Table 1). Variability of ALP was intermediate, and only rarely could lesion scores be differentiated on the basis of ALP values. Variability of ALT and GGT was minimal and measured values were never greater than $17 \mathrm{U} \mathrm{l}^{-1}$ (Table 5). However, correlations of $\log _{e}$ ALT with total bilirubin $(r=0.493)$ and gonad weight ( $r=0.335$ ) were highly significant.

Albumin and total protein were unusually low (Table 5) when compared to published values for other fish species (McDonald \& Milligan 1992), and albumin was particularly low after fish had finished spawning. For example, 16 fish had albumin $\leq 0.3 \mathrm{mg} \mathrm{dl}^{-1}$, but only one of these fish had a gonad weight greater than 
Table 4. Clupea pallasi. Linear correlations ( $r$ ) of age (yr), body weight and gonad weight (g), standard length (mm), hold time (min), albumin ( $\mathrm{g} \mathrm{dl}^{-1}$ ), sum-Ichthyophonus (sumICH) scores, and blood values in Pacific herring sampled from Prince William Sound, Alaska, during spawning, 1994. Highly significant correlations ( $p<0.01)$ are denoted ("); sample size varies from 208 to 233

\begin{tabular}{|c|c|c|c|c|c|c|c|}
\hline Variable & Age & Body weight & Length & Gonad weight & Hold time & sumICH & Albumin \\
\hline Body weight & $0.67^{\circ}$ & & & & & & \\
\hline Length & $0.71^{\circ}$ & $0.90^{\circ}$ & & & & & \\
\hline Gonad weight & $0.36^{\circ}$ & $0.75^{\circ}$ & $0.50^{\bullet}$ & & & & \\
\hline Hold time & -0.15 & $-0.24^{\circ}$ & $-0.20^{\bullet}$ & -0.16 & & & \\
\hline SumlCH & -0.06 & -0.04 & -0.07 & 0.08 & 0.03 & & \\
\hline Albumin & 0.13 & $0.30^{\circ}$ & $0.18^{\circ}$ & $0.34^{\circ}$ & -0.13 & 0.04 & \\
\hline $\operatorname{PCV}(\%)$ & 0.07 & $0.27^{\bullet}$ & $0.17^{\bullet}$ & $0.29^{\circ}$ & -0.14 & -0.16 & $0.38^{\circ}$ \\
\hline Total protein $\left(\mathrm{g} \mathrm{dl}^{-1}\right)$ & 0.11 & $0.36^{\circ}$ & $0.18^{\circ}$ & $0.52^{\circ}$ & -0.08 & $0.21^{\circ}$ & $0.75^{\circ}$ \\
\hline $\log _{e} \operatorname{AST}\left(\mathrm{UL}^{-1}\right)$ & -0.04 & 0.09 & -0.01 & $0.23^{\circ}$ & -0.03 & $0.26^{*}$ & 0.17 \\
\hline $\operatorname{ALP}\left(\mathrm{U} \mathrm{1}^{-1}\right)$ & 0.03 & $0.30^{\circ}$ & 0.11 & $0.46^{\circ}$ & $-0.19^{\circ}$ & 0.10 & $0.58^{\circ}$ \\
\hline $\log _{e} \operatorname{ALT}\left(U 1^{-1}\right)$ & -0.03 & 0.02 & -0.04 & $0.33^{\circ}$ & $0.19^{\circ}$ & 0.02 & 0.05 \\
\hline $\log _{e} \operatorname{CPK}\left(\mathrm{U} \mathrm{l}^{-1}\right)$ & 0.06 & $0.20^{\circ}$ & 0.14 & $0.24^{\circ}$ & -0.10 & $0.30^{\circ}$ & $0.34^{\circ}$ \\
\hline GGT (U 1 $\left.1^{-1}\right)$ & $<0.01$ & 0.09 & 0.06 & 0.02 & -0.23 & 0.09 & 0.16 \\
\hline Calcium (mg dl-1) & $<0.01$ & 0.14 & 0.04 & $0.28^{\circ}$ & -0.13 & -0.03 & $0.44^{\circ}$ \\
\hline Chloride (mmol l-1) & 0.16 & $0.17^{\circ}$ & $0.24^{\bullet}$ & 0.05 & -0.14 & -0.03 & 0.09 \\
\hline Cholesterol (mg di ${ }^{-1}$ ) & 0.10 & $0.27^{\bullet}$ & 0.14 & $0.34^{\circ}$ & -0.17 & 0.09 & $0.90^{\circ}$ \\
\hline $\mathrm{CO}_{2}\left(\mathrm{mmol} \mathrm{l}^{-1}\right)$ & -0.02 & -0.12 & -0.09 & -0.21 & $0.44^{\circ}$ & $<0.01$ & -0.03 \\
\hline Glucose (mg dl-1) & 0.16 & $0.22^{\circ}$ & 0.16 & $0.26^{\circ}$ & $-0.33^{\bullet}$ & -0.05 & $0.37^{\circ}$ \\
\hline Osmolality (mOsm $\mathrm{kg}^{-1}$ ) & 0.08 & $0.27^{\bullet}$ & $0.20^{\bullet}$ & $0.28^{\circ}$ & -0.11 & -0.07 & $0.30^{\circ}$ \\
\hline Phosphorus (mg dl $\left.l^{-1}\right)$ & 0.01 & 0.15 & 0.03 & $0.31^{\bullet}$ & -0.10 & 0.02 & $0.24^{\circ}$ \\
\hline Potassium (mmol l-1) & -0.05 & -0.03 & -0.06 & 0.03 & $0.48^{\circ}$ & 0.08 & 0.03 \\
\hline Total bilirubin ( $\mathrm{mg} \mathrm{dl}^{-1}$ ) & -0.05 & -0.03 & -0.10 & 0.11 & 0.13 & -0.14 & 0.06 \\
\hline
\end{tabular}

$5 \mathrm{~g}$. Total protein values derived from refractometer readings were consistently greater than values derived from the biuret method (mean difference $=3.1 \mathrm{~g} \mathrm{dl}^{-1}$, range $=1.6$ to $4.4 \mathrm{~g} \mathrm{dl}^{-1}$ ); therefore, only values derived from the biuret method were used.

Postspawning fish commonly had clear, highly proteinaceous fluid in the peritoneal cavity (ascites). In most cases, the fluid clotted as it was aspirated into $1 \mathrm{ml}$ syringes for volume measurements. Forty-three fish had 0.1 to $2.5 \mathrm{ml}$ of ascites, and no fish with gonad weight greater than $5 \mathrm{~g}$ had ascites. Ascites was more frequent in males $(26$ of $116,22 \%)$ than in females (17 of $116,17 \%$ ), but differences were not significant (chi-square test, $2 \times 2$ contingency table). Fish with ascites had albumin levels that varied from 0.0 to $0.6 \mathrm{~g} \mathrm{dl}^{-1}$, and albumin levels in fish without ascites ranged from 0.0 to $1.1 \mathrm{~g} \mathrm{dl}^{-1}$.

Multiple regression analysis was used to model a multifactor ANOVA, examining the relationships between the dependent variable albumin and 3 variables (focal skin reddening, splenic congestion, and VHSV). Iris reddening, which was significant in the univariate analysis, was left out of the regression because fewer cases were scored on this variable, contributing to a loss of 19 cases in the analysis. Based on the responses from $205 \mathrm{fish}, 7 \mathrm{fac}$ tors were entered in the final model (gender, gonad weight, hold time, length, focal skin reddening, splenic congestion, and VHSV); the adjusted $r^{2}$ was 0.38 . A stepwise regression equation derived from significant

Table 5. Clupea pallasi. Plasma chemistry values in 233 Pacific herring sampled from Prince William Sound, Alaska, during spawning, 1994

\begin{tabular}{|c|c|c|c|c|c|c|}
\hline \multirow{2}{*}{ Plasma chemistry } & \multirow{2}{*}{ Mean } & \multirow{2}{*}{ Minimum } & \multirow{2}{*}{ Maximum } & \multirow[t]{2}{*}{ SD } & \multicolumn{2}{|c|}{ Normal } \\
\hline & & & & & Low & High \\
\hline Total protein $\left(\mathrm{g} \mathrm{dl}^{-1}\right)$ & 2.2 & 0.2 & 3.8 & 0.6 & 1.0 & 3.1 \\
\hline Albumin $\left(\mathrm{g} \mathrm{dl}^{-1}\right)$ & 0.5 & 0 & 1.1 & 0.2 & 0.1 & 0.8 \\
\hline $\operatorname{ALP}\left(\mathrm{U} \mathrm{l}^{-1}\right)$ & 55 & 2 & 116 & 21 & 13 & 95 \\
\hline $\operatorname{ALT}\left(\mathrm{U} \mathrm{l}^{-1}\right)$ & 3.7 & 0 & 14 & 2 & 0 & 8 \\
\hline $\operatorname{AST}\left(\mathrm{U} \mathrm{I}^{-1}\right)$ & 346 & 11 & 2590 & 318 & 0 & 860 \\
\hline CPK $\left(\mathrm{U} \mathrm{l}^{-1}\right)$ & 450 & 10 & 8080 & 705 & 0 & 1240 \\
\hline $\operatorname{GGT}\left(\mathrm{U}^{-1}\right)$ & 7 & 0 & 17 & 4 & 0 & 15 \\
\hline Potassium $\left(\mathrm{mmol} \mathrm{l}^{-1}\right)$ & 2.3 & 0.6 & 7.7 & 1.1 & 0 & 4.4 \\
\hline Chloride (mmol l-1) & 163 & 141 & 197 & 12 & 139 & 184 \\
\hline $\mathrm{CO}_{2}\left(\mathrm{mmol} \mathrm{l}^{-1}\right)$ & 6 & 0 & 17 & 2 & 1.7 & 10.3 \\
\hline Phosphorus (mg dl ${ }^{-1}$ ) & 12.7 & 5.5 & 38 & 4.3 & 3.7 & 21.5 \\
\hline Calcium (mg dl ${ }^{-1}$ ) & 11.6 & 6.7 & 21 & 1.9 & 7.9 & 14.8 \\
\hline Cholesterol (mg di-1) & 218 & 4 & 420 & 71 & 74 & 353 \\
\hline Glucose $\left(\mathrm{mg} \mathrm{dl}^{-1}\right)$ & 83 & 17 & 411 & 39 & 3 & 164 \\
\hline Total bilirubin (mg dl-1 & 0.04 & 0 & 0.4 & 0.08 & 0 & 0.2 \\
\hline Osmolality (mOsm $\mathrm{kg}^{-1}$ ) & 428 & 374 & 512 & 24.6 & 378 & 475 \\
\hline
\end{tabular}


factors only was used to quantify the contribution of each variable to albumin levels $\left(\mathrm{g} \mathrm{dl}^{-1}\right)$. The constant $\left(0.21 \mathrm{~g} \mathrm{dl}^{-1}\right)$ is altered as follows:

\begin{tabular}{|c|c|}
\hline gender male $=$ & +0.114 \\
\hline gender female $=$ & +0.000 \\
\hline gonad weight $(g)=$ & $+0.0045 \times($ gonad $w t)$ \\
\hline VHSV-negative $=$ & +0.047 \\
\hline VHSV-positive $=$ & -0.047 \\
\hline focal skin reddening, none = & +0.098 \\
\hline focal skin reddening, mild = & -0.006 \\
\hline $\begin{array}{r}\text { focal skin reddening, } \\
\text { moderate/severe }=\end{array}$ & -0.104 \\
\hline splenic congestion, none $=$ & +0.046 \\
\hline splenic congestion, mild = & -0.008 \\
\hline $\begin{array}{l}\text { splenic congestion, } \\
\text { moderate/severe }=\end{array}$ & -0.038 \\
\hline
\end{tabular}

For example, a male $(+0.114)$ with a gonad weight of $10 \mathrm{~g}(+0.045)$ that was VHSV negative $(+0.047)$ and had no focal skin reddening $(+0.098)$ and mild splenic congestion $(-0.008)$ would be expected to have a plasma albumin level of $0.51 \mathrm{~g} \mathrm{dl}^{-1}$. The predicted plasma albumin level in a similar male with moderate focal skin reddening would decrease to $0.30 \mathrm{~g} \mathrm{dI}^{-1}$.

Like albumin, scores for several lesions and other variables could be differentiated on the basis of PCV, and PCV was significantly associated with several plasma chemistries (Tables 1 \& 4). Multiple regression analysis was used to model a multifactor ANOVA, examining the relationships between PCV and 7 variables. Based on the results from 186 fish, 12 factors were entered in the final model (gender, gonad weight, hold time, length, osmolality, focal skin reddening, splenic Ichthyophonus, renal hematopoietic cells, hepatic lipidosis, cardiac thrombosis, gastric trematodes, and VHSV); the adjusted $r^{2}$ was 0.29 .
Because of the potential that dehydration could effect $\mathrm{PCV}$, osmolality was added as a controlling variable. A stepwise regression equation derived from significant factors only was used to quantify the contribution of each variable to PCV (\%). The constant $(51.14 \%)$ is altered as follows:

\begin{tabular}{|c|c|}
\hline gender male $=$ & +2.30 \\
\hline gender female $=$ & +0.00 \\
\hline gonad weight $(g)=$ & $+0.1513 \times($ gonad $w t)$ \\
\hline osmolality $(\mathrm{mOsm} / \mathrm{kg})=$ & $-0.0433 \times$ (osmolality) \\
\hline hepatic lipidosis, none $=$ & +1.49 \\
\hline $\begin{array}{l}\text { hepatic lipidosis, mild = } \\
\text { hepatic lipidosis, }\end{array}$ & -0.71 \\
\hline moderate/severe $=$ & -0.77 \\
\hline splenic Ichthyophonus, none $=$ & $=+1.50$ \\
\hline splenic Ichthyophonus, mild = & -2.43 \\
\hline $\begin{array}{l}\text { splenic Ichthyophonus, } \\
\text { moderate/severe }=\end{array}$ & +0.92 \\
\hline $\begin{array}{l}\text { renal hematopoietic cells, } \\
\text { none }=\end{array}$ & -2.29 \\
\hline $\begin{array}{l}\text { renal hematopoietic cells, } \\
\text { mild }=\end{array}$ & +1.63 \\
\hline $\begin{array}{l}\text { renal hematopoietic cells, } \\
\text { moderate }=\end{array}$ & +0.67 \\
\hline gastric trematodes, none $=$ & +1.87 \\
\hline $\begin{array}{l}\text { gastric trematodes, } \\
\text { mild } / \text { moderate }=\end{array}$ & -1.87 \\
\hline
\end{tabular}

For example, a male $(+2.30)$ with a gonad weight of $10 \mathrm{~g}(+1.51)$, osmolality of $425 \mathrm{mOsm} \mathrm{kg}^{-1}(-18.40)$, no hepatic lipidosis $(+1.49)$, no splenic Ichthyophonus $(+1.50)$, mild renal hematopoietic cells $(+1.63)$, and mild gastric trematodes $(-1.87)$ would be expected to have a PCV of $39.3 \%$. By comparison, a similar male with no renal hematopoietic cells and mild splenic Ichthyophonus would have a predicted PCV of $31.5 \%$.

Table 6. Clupea pallasi. Sample prevalence $(\%)$ of parasites and virus in adult Pacific herring in Prince William Sound, Alaska, 1989 to 1994

\begin{tabular}{|c|c|c|c|c|c|}
\hline Sample date & $\mathrm{n}$ & $\begin{array}{c}\text { Goussia } \\
\text { clupearum }\end{array}$ & $\begin{array}{c}\text { Ichthyophonus } \\
\text { hoferi }\end{array}$ & $\begin{array}{c}\text { Ortholinea } \\
\text { orientalis }\end{array}$ & $\begin{array}{c}\text { Viral hemorrhagic } \\
\text { septicemia virus }\end{array}$ \\
\hline 1989 April ‘ & 40 & 63 & 13 & $T_{N E}^{b}$ & TNE \\
\hline 1990 October $^{\text {d }}$ & 99 & 60 & 15 & 12 & TNE \\
\hline 1991 Aprila $^{a}$ & 59 & 54 & 5.1 & 17 & TNE \\
\hline 1991 October $^{d}$ & 48 & 54 & 2.1 & 15 & TNE \\
\hline 1992 April $^{\circ}$ & 105 & 53 & 5.7 & 3.1 & TNE \\
\hline 1993 April d $^{\text {d }}$ & 79 & 41 & 5.1 & 4.3 & 2 of 35 -fish pools \\
\hline 1994 April & 212 & 61 & 29 & $5.7^{\circ}$ & 4.7 \\
\hline \multicolumn{6}{|c|}{$\begin{array}{l}\text { Unpubl. data from G. D. Marty, M. S. Okihiro, and D. E. Hinton } \\
\text { 'TNE: Tissue not examined } \\
\text { CKocan et al. (1996) } \\
\text { dMeyers et al. (1994), Meyers \& Winton (1995) } \\
\text { Prevalence based on histopathology only; total prevalence using touch preparations and histopathology was } 19 \%\end{array}$} \\
\hline
\end{tabular}




\section{Annual trends in spawning biomass and pathogen prevalence}

Sample prevalence of Ichthyophonus in this study was almost twice that of previous years (Table 6). During the damage assessment phase of study from 1989 through 1992, and disease studies in 1993 (Meyers et al. 1994), prevalence of Ichthyophonus in Pacific herring sampled from PWS was never more than 15\% By comparison, prevalence of Goussia clupearum has remained fairly constant between 41 and $63 \%$, and Ortholinea orientalis prevalence has not exceeded $17 \%$. The slight increase in Ortholinea orientalis prevalence in this study $(19 \%)$ was probably at least partly due to increased efficiency of diagnosis when touch preparations were examined; previous prevalence data were derived from histopathology only. Prevalence of VHSV and other parasites was not determined in previous studies because appropriate tissues were not examined.

\section{DISCUSSION}

\section{VHSV}

The North American strain of VHSV was a major cause of morbidity in Pacific herring in PWS during spawning in 1994. Fish from which VHSV was isolated had significant gross lesions as well as microscopic lesions in the gills, liver, stomach, arteries, and heart. Most lesions were consistent with a disseminated endotheliotrophic virus, and lesions such as coagulative necrosis in the liver have been attributed to VHSV in natural and laboratory infections in rainbow trout (Amlacher et al. 1980, Wolf 1988b). Because the VHSV outbreak was nearly over in 1994 , opportunities to confirm association of lesions with VHSV by further field study have been limited. However, recent study with Pacific herring fulfilled Koch's postulates, demonstrating that VHSV kills laboratory-reared Pacific herring in absence of other pathogens (Kocan et al. 1997).

Although the North American strain of VHSV has been isolated from several populations of Pacific herring (Meyers \& Winton 1995), the only other published report of VHSV linked to population decline was from fish sampled in PWS in 1993 (Meyers et al. 1994). Meyers et al. (1994) postulated that several lesions were associated with VHSV: subdermal and renal hemorrhages, kidney tubule degeneration, and active reticuloendothelial cell foci in the kidneys. Also, active reticuloendothelial cell foci in the liver were associated with hepatocellular necrosis. In the present study, we confirmed an association of VHSV with fin base reddening and focal coagulative hepatic necrosis, and we had some evidence for association of VHSV with ulcers (i.e. severe focal skin reddening). Association of VHSV with renal hemorrhage or kidney tubule degeneration could not be confirmed. In the present study, 'active reticuloendothelial cells' were classified as either pigmented macrophage aggregates or granulomatous inflammation, and neither was significantly related to VHSV in the liver or kidney. However, infiltrates of lymphocytes or macrophages in the gastric submucosa, gill arches, and brain were significantly associated with VHSV infection. In a study of PWS Pacific herring from 1992, granulomatous inflammation was associated with decreased reproductive success (Kocan et al. 1996), but based on our results we cannot attribute these lesions to VHSV.

Population fluctuations in Pacific herring are considered normal by management biologists, but in only one other case was population decline attributed to disease. During February and March of 1942, 'several thousands of tons' of Pacific herring were found dead along the southeast coast of Vancouver Island, British Columbia, Canada (Tester 1942). 'The dying fish came to the surface and could, while still alive, be picked up by gulls or by hand.' Mortality involved pre- and postspawners, and fish continued to be lethargic and school in shallow water near shore until mid-May (Tester 1942). Diagnostic examination included gross necropsy, bacteriology, blood smears, and parasite screen, but no significant pathogens were found. Based on this level of diagnostic detail, Ichthyophonus can be ruled out as the cause of mortality in 1942, but many features were similar to the 1993 epizootic in PWS. Both outbreaks had lethargic fish, some of which had reddening of the fins, and both outbreaks followed a year in which commercial harvest was above average. The epizootic near Vancouver Island involved a dominant 1938 year class (4-yr-olds), whereas the PWS epizootic involved a dominant 1988 year class (5-yrolds). As a difference, the Vancouver Island outbreak had large numbers of dead fish, whereas dead fish were not reported in the PWS epizootic. One other disease, VEN, has been reported to cause significant mortality in juvenile Pacific herring when such year classes are strong. However, VEN has not been associated with significant decline in population biomass (Meyers et al. 1986), and PWS fish in 1994 had no evidence of VEN

Several questions about the pathogenesis of VHSV in Pacific herring are beginning to be answered with continued field study and focused laboratory study. VHSV is highly infectious, spreads through the water, and readily kills disease-free Pacific herring independent of exposure to other pathogens (Kocan et al. 1997). Preliminary field and laboratory studies indicate that 10 to $15 \%$ of Pacific herring have sub. 
clinical infections but express VHSV and the associated disease only when subjected to stress (R. M. Kocan pers. comm., G. D. Marty unpubl obs.). A related virus, infectious hematopoietic necrosis virus (IHNV, also in the family Rhabdoviridae), is commonly carried by salmonids. Disease from IHNV is generally a serious problem only in juvenile fish, and virus is expressed in surviving adults during and after spawning (Wolf 1988a). In a study of Pacific herring at the National Marine Fisheries Service Laboratory in Auke Bay, Alaska, VHSV was expressed in a dose-dependent manner after $17 \mathrm{~d}$ of exposure to weathered crude oil (Mark Carls pers. comm., Meyers \& Winton 1995). Although the VHSV status of these fish before the study began was unknown, the study provided evidence that oil can act as a stressor that activates VHSV. Several other questions are under investigation. Once VHSV is expressed, can fish mount a successful immune response and overcome the disease? Does virus expression cycle seasonally? What environmental factors contribute to disease and immunity?

\section{Ichthyophonus hoferi}

Ichthyophonus has not previously been described as a major cause of mortality in Pacific herring, but in Atlantic herring several epizootics of Ichthyophonus have been linked to population decline (Fish 1934, Sindermann 1958, Patterson 1996). Indeed, Ichthyophonus hoferi is the most commonly reported and most severe marine fungal pathogen, and 'this disease may be the most important single limiting factor to population growth of herring in the western North Atlantic (Sindermann 1970). Although recent evidence indicates that Ichthyophonus is not a fungus (Spanggaard et al. 1996), its biological significance remains unchanged. Outbreaks in Atlantic herring tend to begin during biomass peaks, usually lasting 2 to $3 \mathrm{yr}$, and recovery often takes more than 3 yr (Sindermann 1970 , Mellergaard \& Spanggaard 1997). In Pacific herring in PWS, peak biomass in 1989 did not result in a major Ichthyophonus-related population decline, but severe population decline in 1993 was followed by a sharp increase in Ichthyophonus prevalence in 1994. Previous declines in Pacific herring biomass have been recorded in PWS, but these were attributed to poor year-class recruitment and over-fishing (Rounsefell \& Dahlgren 1932). In Atlantic herring in the Gulf of Maine, Ichthyophonus was considered the cause of population declines in 1931 and 1947, and anecdotal evidence was strong for Ichthyophonus as the major cause of population declines in 1898 and 1916 (Fish 1934, Sindermann 1965). From 1898 to 1947 , outbreaks occurred about every $16 \mathrm{yr}$ and this trend held for 4 cycles; however, no Ichthyophonus outbreaks have been documented in the Culf of Maine since 1947. Sporadic but significant Ichthyophonus outbreaks have also been described in the Gulf of St. Lawrence (Sindermann 1970). In Europe, Ichthyophonus was not associated with Atlantic herring population decline until a 1991 epizootic in the North Sea (Patterson 1996. Rahimian \& Thulin 1996, Mellergaard \& Spanggaard 1997).

Some features of Ichthyophonus infection in PWS Pacific herring were different from those described in wild Atlantic herring. For example, Atlantic herring with severe infections often had gross lesions in the muscle described as 'rough or granulomatous skin' or 'sandpaper effect' (Post 1987); associated ulcers have been termed 'pepper effect', partly as a result of pigment deposition in the lesions (Fish 1934). By comparison, Pacific herring had no gross external lesions directly associated with Ichthyophonus, and microscopic lesions in the skin and skeletal muscles were usually mild. Further, Pacific herring had no pigment associated with Ichthyophonus resting spores. Another difference was that epizootics in North American Atlantic herring were always characterized by large numbers of moribund and dead fish in shallow areas (Fish 1934, Sindermann 1958), whereas there were no confirmed reports of dead fish in PWS. Not all features of Ichthyophonus were different in Atlantic and Pacific herring; multifocal to coalescing granulomas in internal organs of PWS Pacific herring were similar to the descriptions of gross and histologic lesions reported in Atlantic herring.

The epizootiology of Ichthyophonus infection in Pacific herring in PWS is still unclear with only 7 samples in 6 years from 1989 through 1994. Many questions remain unanswered: (1) What is the latency period between Ichthyophonus exposure and overt signs of disease? (2) When Ichthyophonus is diagnosed histologically, how long will the affected fish live? (3) Can a fish, once infected, initiate a successful immune response and overcome the disease, or are all infected fish destined to die? and (4) Because Ichthyophonus prevalence was only $5 \%$ in 1993 despite significant population decline (Meyers et al. 1994), how important is Ichthyophonus as a cause of Pacific herring mortality? The large spike in Ichthyophonus prevalence in this study $(29 \%)$ was unexpected, but was consistent with infection levels of about $25 \%$ described in epizootics affecting Atlantic herring (Sindermann 1970). Sindermann (1970) stated that enzootic levels were about $1 \%$, lower than any samples from Pacific herring in PWS, but Sindermann's observations were based only on gross examination to determine prevalence. Method of 
diagnosis can make a significant difference in the number of positive cases identified (Holst 1994, Rahimian \& Thulin 1996), and in our study, results from gross examination underestimated the number of infected fish.

In Pacific herring from our study, CPK and AST values could be used to differentiate Ichthyophonus lesion scores in nearly every organ. Creatine phosphokinase is a dimeric enzyme with isoenzyme types $C K_{1}$ (BB, brain), $\mathrm{CK}_{2}\left(\mathrm{MB}\right.$, heart), and $\mathrm{CK}_{3}$ (MM, skeletal muscle). In mammals, the brain form of CPK is not found in plasma, even during neurologic disease (Duncan \& Prasse 1986); therefore, the finding that brain Ichthyophonus status was the best predictor for increased CPK in our study was unexpected. Brain Ichthyophonus was uncommon, but the high mean sumICH score for fish with brain Ichthyophonus (Fig. 6) provided evidence that Ichthyophonus was disseminated when it appeared in the brain. That is, if Ichthyophonus was disseminated sufficiently that it affected the brain, then the fish probably also had muscle Ichthyophonus severe enough to increase CPK. Further, $79 \%$ of muscle Ichthyophonus cases were mild, and the damage caused by these muscle lesions was probably not sufficient to increase CPK. Alternatively, the brain form of CPK might be released during neurologic disease in Pacific herring. Isoenzyme analysis on plasma from Ichthyophonus-positive Pacific herring has not been successful (C. Kennedy, Simon Fraser University, Burnaby, British Columbia, Canada, pers. comm.).

For AST in mammals, lesions in liver, muscle, and blood-rich organs are most highly associated with increased enzyme levels (Duncan \& Prasse 1986). For Pacific herring, renal Ichthyophonus status was significant in all regressions, but spleen and heart were not. Most likely, the disseminated nature of Ichthyophonus infections prevented localization of the source of AST in infected fish.

The effects of Ichthyophonus infection on plasma chemistries have not previously been described in natural epizootics. In laboratory-exposed rainbow trout Oncorhynchus mykiss, Ichthyophonus infection was associated with anemia and leukopenia, but did not change plasma chloride, creatinine, glucose, osmolarity, potassium, total protein, sodium, or T4 (Rand \& Cone 1990); enzymes CPK and AST were not measured. In addition to increased CPK and AST in this study, IChthyophonus infection was significantly associated with anemia and variable plasma protein levels; white blood cells were not counted. Based on the equation derived from multifactor analysis, a fish with mild splenic Ichthyophonus would be predicted to have a $\mathrm{PCV}$ that was $4 \%$ less than a similar fish with no splenic Ichthyophonus

\section{Other potential pathogens}

A few comprehensive reports are available on the prevalence of parasites in Pacific herring, and their potential role in stock identification (Arthur \& Arai 1980, Moser \& Hsieh 1992). The purpose of our study was not to repeat these studies, but to determine which of the common parasites of Pacific herring in PWS could potentially contribute to population decline. More than 30 species of parasites have been described from Pacific herring (Arthur \& Arai 1980). In our study, 10 parasites occurred in prevalences sufficient to study their role in disease and population decline. Two criteria were used to determine if a parasite caused significant damage to the host: (1) Was the parasite associated with histopathologic damage, particularly inflammation? and (2) Was infection with the parasite associated with alterations in plasma chemistries? Using these criteria, linkage of damage to infections by parasites other than Ichthyophonus was not clear.

The intraductal renal myxosporean Ortholinea orientalis was not associated with morphologic lesions, nor was there metastatic calcification, but fish with large numbers of organisms had elevated plasma calcium. Because the kidney is one organ that excretes calcium (Dacke 1979), large numbers of organisms might have impaired calcium excretion. The relation of intraductal parasites and calcium levels has not previously been described, and this effect would need to be confirmed by controlled laboratory study.

Lymphocystis virus has been identified in fibroblasts of over 150 species of fish, including Atlantic herring (listed by Lawler et al. 1977), but this is the first description of lymphocystis virus in Pacific herring. Also, in most reported cases, lymphocystis lesions are limited to the skin (Post 1987). Our finding of lymphocystis lesions limited to solitary nodules within the peritoneal cavity is unusual.

\section{Gender- and age-associated lesions}

Lower plasma albumin levels in females than in males could partly be explained by vitellogenin synthesis in females. In the hepatocyte, estradiol activates the vitellogenin gene, but production of albumin is depressed (Mommsen \& Walsh 1988). Low plasma albumin is commonly associated with ascites in mammals, and Pacific herring with ascites tended to have lower albumin levels than fish without ascites; however, females were not more likely to develop ascites than were males. Several other plasma chemistries and lesion scores had significant gender differences, but little information is available to explain these differences in Pacific herring 
We could critically evaluate only one age-related hypothesis regarding the link between the oil spill and disease in 1994. Fish that were hatched or were yearlings in 1989 at the time of the spill (1988 and 1989 year classes) might have incurred irreversible immunosuppression. Under normal growth conditions, minor deficiencies in their immune system might have been insignificant. However, disease might have become a serious problem when fish experienced additional stress upon first spawning (1992 and 1993). Stress is welldocumented as a cause of immunosuppression, but stress-induced changes usually are reversible if the fish survives (Anderson 1990). We found that several changes were significantly associated with age, but scores for nearly all these changes were greater in older fish (i.e. fish hatched before 1988). Also, among VHSV, Ichthyophonus, and 10 other common parasites, none were more prevalent in the 1988 and 1989 year classes than in the entire sampled population. Annual ageweight-length analysis by the Alaska Department of Fish and Game has documented that the population decreased in the absence of abnormal changes in age distribution (Fritz Funk unpubl. data). Therefore, the weight of evidence suggests that the disease outbreak in PWS was not a result of permanent immune suppression caused by hydrocarbon exposure when fish were larvae or yearlings. A companion study in Prince William Sound reached similar conclusions (Elston et al. 1997).

\section{Alterations in plasma chemistries}

Analysis of plasma chemistry values was inexpensive and provided useful information for evaluating health of Pacific herring in PWS. However, interpretation of results was limited by lack of reference values. In the only published study of normal plasma enzyme values in Pacific herring (Márquez 1976), analysis of electrolytes and other nonenzyme chemistries was not included. Márquez (1976) captured 5 to 12 Pacific herring by angling, held the fish for $12 \mathrm{~h}$, and then drew blood to analyze for plasma enzymes at $30^{\circ} \mathrm{C}$. His mean values for CPK (2948 $\mathrm{U} \mathrm{l}^{-1}$ ) and AST (1778 $\mathrm{U} \mathrm{l}^{-1}$ ) were more than twice the maximum values of normal ranges established in our study (Table 5). Differences between the 2 studies probably resulted from Márquez performing analyses at $30^{\circ} \mathrm{C}$ instead of the $25^{\circ} \mathrm{C}$ of our study. Also, the $12 \mathrm{~h}$ hold time might have been long enough so that increased enzyme levels reflected damage that occurred during capture. In our study, hold time of less than $<4$ h was not significantly correlated with plasma CPK or AST. Reference values from Pacific herring populations in peak condition (e.g. late summer) are needed to better interpret changes associated with spawning.
Interesting findings in plasma chemistry values included unusually low albumin levels and unusually high osmolality. Altered plasma chemistry valucs have been associated with spawning in other fish species, but abnormalities were transient (McDonald \& Milligan 1992). Because albumin levels in Pacific herring were significantly decreased only at the end of spawning, and ascites occurred most often in spawned out fish, development of ascites was probably related to physiologic changes at the end of spawning.

Total plasma protein values determined using a refractometer were higher than values determined by colorimetry. Similar differences have been documented in other fish species (Hunn \& Greer 1990, Hunn et al. 1992), but the molecular cause for this difference has not been determined. Subsequent analysis of total plasma protein in Pacific herring has used only the colorimetry technique.

Plasma glucose, $\mathrm{CO}_{2}$, and potassium were useful markers of the effects of hold time between capture and necropsy. The increase in plasma $\mathrm{CO}_{2}$ was indicative of respiratory acidosis, and potassium levels are expected to increase during acidemia (McDonald \& Milligan 1992). Decreased glucose levels may have been associated with increased anaerobic glycolysis, but lactate levels were not determined. Normally, capture stress resuits in hyperglycemia (Hopkins \& Cech 1992), but Pacific herring hepatocytes had histologic evidence of minimal glycogen, thereby limiting the ability of the liver to increase plasma glucose levels in response to stress. To determine the relation of hold time to metabolic acidosis and other plasma chemistry values, plasma lactate levels have been analyzed in continuing Pacific herring disease studies (G. D. Marty unpubl. data).

\section{Implications for studies of disease epizootics in fish populations}

Disease epizootics have been associated with declining populations of several marine fish species during the past century. Most notably, early work identified Ichthyophonus as the major cause of population decline in Atlantic herring in the Northwest Atlantic (Daniel 1933a, Fish 1934, Sindermann 1970). When Ichthyophonus prevalence was high in North Sea Atlantic herring in 1991, Ichthyophonus was assumed to be the primary cause of population decline. An extensive, multiyear study focused on Ichthyophonus to determine the effects of season, fish age, and gear type on sample prevalence (Holst 1996, Patterson 1996, Rahimian \& Thulin 1996, Mellergaard \& Spanggaard 1997). Comparatively little effort was expended to determine if other pathogens, particularly viruses 
were contributing to the epizootic. The recent isolation of the European strain of VHSV from Atlantic herring (Dixon et al. 1997) introduces a new hypothesis into the interpretation of the Ichthyophonus findings. Was Ichthyophonus the primary cause of the epizootic described in Atlantic herring? Or, did an increase in Ichthyophonus prevalence follow an outbreak of VHSV that went undetected?

In other epizootics, a broader range of diagnostic techniques was used to identify the source of the epizootic. For dying striped bass Morone saxatilis sampled from an estuary, histopathology was combined with plasma chemistry and toxicant analysis, but virus isolation was not attempted and the cause of death was not determined (Young et al. 1994). For dying pilchard Sardinops sagax, a herpesvirus was consistently identified on histological and ultrastructural analysis of the gills of sick fish (Hyatt et al. 1997, Whittington et al. 1997), but the virus could not be cultured in vitro (study was limited by lack of pilchard cell lines for virus isolation). Underlying causes of these epizootics and the Pacific herring epizootic are not fully understood (Meyers \& Winton 1995). However, through comprehensive pathological examination, combined with focused laboratory study, we have shown that significant pathogens and risk factors can be identified and many variables can be ruled out as significant causes of population decline. Study of disease in PWS Pacific herring has been expanded to include a reference site and semiannual study through spring of 1998. Decreasing prevalence of VHSV and Ichthyophonus has been accompanied by an increasing fish population. Future papers will detail the results of these studies.

Acknowledgements. We thank J Vansant, D. Branshaw, D. C Phipps, and C. T. Stack for finding and capturing the fish, and W. Widmann for sectioning tissues. Corrine R. Davis performed half of the necropsies and all gonad histopathology. Adam Moles helped identify the parasites, and Joseph R. Sullivan and Barbara S. Washburn reviewed the project design. The research described in this paper was supported by the 'Exxon Valdez' Oil Spill Trustee Council through contracts with the Alaska Department of Fish and Game. However, the findings and conclusions presented by the authors are their own and do not necessarily reflect the views or position of the Trustee Council.

\section{LITERATURE CITED}

Amlacher E, Ude J, Rudolph C, Ernst G (1980) Direct electron microscopical visualization of the presumptive virus of viral haemorrhagic septicaemia (VHS) in the rainbow trout Salmo gairdneri Richardson and additional histopathological and haematological observations. J Fish Dis 3:55-62

Anderson DP (1990) Immunological indicators: effects of environmental stress on immune protection and disease outbreaks. Am Fish Soc Symp 8:38-50
Arthur JR, Arai HP (1980) Studies on the parasites of Pacific herring (Clupea harengus pallasi Valenciennes): survey results. Can J Zool 58:64-70

Dacke CG (1979) Calcium regulation in sub-mammalian vertebrates. Academic Press, New York

Daniel GE (1933a) Studies on Ichthyophonus hoferi, a parasituc fungus of the herring, Clupea harengus. I. The parasite as it is found in the herring. Am J Hyg, Baltimore $17: 262-276$

Daniel GE (1933b) Studies on Ichthyophonus hoferi, a parasitic fungus of the herring. Clupea harengus. II. The gross and microscopic lesions produced by the parasite. Am $\mathrm{J}$ Hyg, Baltimore 17:491-501

Dixon PF, Feist S, Kehoe E, Parry L, Stone DM, Way K (1997) Isolation of viral haemorrhagic septicaemia virus from Atlantic herring Clupea harengus from the English Channel. Dis Aquat Org 30:81-89

Duncan JR, Prasse KW (1986) Veterinary laboratory medicine. Iowa State University Press, Ames, IA.

Elston RA, Drum AS, Pearson WH, Parker K (1997) Health and condition of Pacific herring, Clupea pallasi from Prince William Sound, Alaska, 1994. Dis Aquat Org 31. $109-126$

Fish FF (1934) A fungus disease of fishes of the Gulf of Maine. Parasitol 26:1-16

Hauck AK, May EB (1977) Histopathologic alterations associated with Anisakis larvae in Pacific herring from Oregon. J Wildl Dis 13:290-293

Holst JC (1994) The precision of two macroscopic screening procedures relative to a microscopic procedure for screening of the fungus Ichthyophonus hoferi in herring (Clupea harengus L.). Fish Res (Amst) 19:187-190

Holst JC (1996) Estimating the prevalence of Ichthyophonus hoferi (Plehn and Mulsow) in a herring stock (Clupea harengus L.): observed effects of sampling gear, target school density and migration. Fish Res 28:85-97

Hopkins TE, Cech JJ Jr (1992) Physiological effects of capturing striped bass in gill nets and fyke traps. Trans Am Fish Soc 121:819-822

Hunn JB, Greer IE (1990) Colorimetric and refractometer estimates of total plasma protein in striped bass, Morone saxatilis (Walbaum). J Fish Biol 36:617-618

Hunn JB, Wiedmeyer RH, Greer IE, Grady AW (1992) Blood chemistry of laboratory-reared golden trout. J Aquat Anim Health 4:218-222

Hyatt AD, Hine PM, Jones JB, Whittington RJ, Kearns C, Wise TG, Crane MS, Williams LM (1997) Epizootic mortality in the pilchard Sardinops sagax neopilchardus in Australia and New Zealand in 1995. II. Identification of a herpesvirus within the gill epithelium. Dis Aquat Org 28:17-29

Jastrzebski M, Komorowski Z (1990) Light and electron microscopic studies on Goussia zarnowskii (Jastrzebski, 1982): an intestinal coccidium parasitizing the threespined stickleback, Gasterosteus aculeatus. J Fish Dis 13: $1-24$

Kocan R, Bradley M, Elder N, Meyers TR, Batts W, Winton J (1997) The North American strain of viral hemorrhagic septicemia virus is highly pathogenic for laboratory reared Pacific herring (Clupea pallasi). J Aquat Anim Health 9: 279-290

Kocan RM, Marty GD, Okihiro MS, Brown ED, Baker TT (1996) Reproductive success and histopathology of individual Prince William Sound herring 3 years after the 'Exxon Valdez' oil spill. Can J Fish Aquat Sci 53:2388--2393

Lawler AR, Ogle JT, Donnes C (1977) Dascyllus spp: new hosts for lymphocystis, and a list of recent hosts. J Wildl Dis 133:307-311 
Márquez ED (1976) A comparison of glutamic-oxalacetate transaminase, lactate dehydrogenase and creatine phosphokinase activities in non-spawning, pre-spawning, and spawning pink salmon. Comp Biochem Physiul 54B: $121-123$

McDonald DG, Milligan CL (1992) Chemical properties of the blood. In: Hoar WS, Randali DJ, Farrell AP (eds) Fish physiology, Vol XIIb, The cardiovascular system. Academic Press, San Diego, CA, p 55-133

McKim JM (1985) Early life stage toxicity tests. In: Rand GM, Petrocelli SR (eds) Fundamentals of aquatic toxicology. Hemisphere, Washington, DC, p 58-95

Mellergaard S, Spanggaard B (1997) An Ichthyophonus hoferi epizootic in herring in the North Sea, the Skagerrak, the Kattegat and the Baltic Sea. Dis Aquat Org 28:191-199

Meyers TR, Hauck AK, Blankenbeckler WD, Minicucci T (1986) First report of viral erythrocytic necrosis in Alaska, USA, associated with epizootic mortality in Pacific herring, Clupea harengus pallasi (Valenciennes). J Fish Dis 9:479-491

Meyers TR, Short S, Eaton W (1990) Summer mortalities and incidental parasitisms of cultured Pacific oysters in Alaska. $J$ Aquat Anim Health 2:172-176

Meyers TR, Short S, Lipson K, Batts WN, Winton JR, Wilcock $J$, Brown E (1994) Association of viral hemorrhagic septicemia virus with epizootic hemorrhages of the skin in Pacific herring Clupea harengus pallasi from Prince William Sound and Kodiak Island, Alaska, USA. Dis Aquat Org 19:27-37

Meyers TR, Winton JR (1995) Viral hemorrhagic septicemia virus in North America. Annu Rev Fish Dis 5:3-24

Mommsen TP, Walsh PJ (1988) Vitellogenesis and oocyte assembly. In: Hoar WS, Randall DJ (eds) Fish physiology, Vol XIa, The physiology of developing fish. Academic Press, San Diego, CA, p 347-406

Morrison CM. Hawkins WE (1984) Coccidians in the liver and testis of the herring Clupea harengus L. Can J Zool 62: $480-493$

Morrison CM, McClelland G, Cornick J, Marcogliese D (1986) Parasites and disease of some marine finfish of Nova Scotia. Can Tech Rep Fish Aquat Sci 1424:1-36

Moser M, Hsieh J (1992) Biological tags for stock separation in Pacific herring Clupea harengus pallasi in California. J Parasitol 78:54-60

Patterson KR (1996) Modelling the impact of disease-induced mortality in an exploited population: the outbreak of the fungal parasite Ichthyophonus hoferi in the North Sea herring (Clupea harengus). Can J Fish Aquat Sci 53:2870-2887

Editorial responsibility: Jo-Ann Leong,

Corvallis, Oregon, USA
Post G (1987) Textbook of fish health. TFH Publications, Neptune City, NJ

Rahimian H, Thulin J (1996) Epizootiology of Ichthyophonus hoferi in hernng populations off the Swedish west coast. Dis Aquat Org 27:187-195

Rand TG, Cone DG (1990) Effects of Ichthyophonus hoferi on condition indices and blood chemistry of experimentally infected rainbow trout (Oncorhynchus mykiss). J Wildl Dis 26:323-328

Rounsefell GA, Dahlgren EH (1932) Fluctuations in the supply of herring, Clupea pallasii, in Prince William Sound, Alaska. Bull US Bur Fish No 9 47:263-291

Short JW, Harris PM (1996) Petroleum hydrocarbons in caged mussels deployed in Prince William Sound after the 'Exxon Valdez' oil spill. Am Fish Soc Symp 18:29-39

Sindermann CJ (1958) An epizootic in Gulf of St. Lawrence fishes. Trans N Am Wildl Conf 23:349-360

Sindermann CJ (1965) Effects of environment on several diseases of herring from the western North Atlantic. Spec Publ Intern Comm Northw Atl Fish 6:603-610

Sindermann CJ (1970) Principal diseases of marine fish and shellfish. Academic Press, New York

Spanggaard B, Skouboe P, Rossen L, Taylor JW (1996) Phylogenetic relationships of the intercellular fish pathogen Ichthyophonus hoferi and fungi, choanoflagellates and the rosette agent. Mar Biol 126:109-115

Tester A.L (1942) Herring mortality along the south-east coast of Vancouver Island. Fish Res Board Can, Prog Rep Pac Coast Stn 52:11-15

Whittington RJ, Jones JB, Hine PM, Hyatt AD (1997) Epizootic mortality in the pilchard Sardinops sagax neopilchardus in Australia and New Zealand in 1995. I. Pathology and epizootiology. Dis Aquat Org 28:1-16

Willard MD, Tvedten H, Turnwald GH (1989) Small animal clinical diagnosis by laboratory methods. WB Saunders Company, Philadelphia, PA

Wolf K (1988a) Infectious hematopoietic necrosis. In: Wolf K (ed) Fish viruses and fish viral diseases. Cornell University Press, Ithaca, NY, p 83-114

Wolf K (1988b) Viral hemorrhagic septicemia. In: Wolf K (ed) Fish viruses and fish viral diseases. Cornell University Press, Ithaca, NY, p 217-249

Young G, Brown CL, Nishioka RS, Folmar LC, Andrews M Cashman JR, Bern HA (1994) Histopathology, blood chemistry, and physiological status of normal and moribund striped bass (Morone saxatilis) involved in summer mortality ('die-off') in the Sacramento-San Joaquin delta of California. J Fish Biol 44:491-512

Submitted: August 14, 1997; Accepted: October 31, 1997 Proofs received from author(s): February 12, 1998 